\title{
The Hypothalamic-Hypophysial Neurosecretory System in the Iguanid Lizard, Dipsosaurus dorsalis: A Qualitative and Quantitative Study
}

\author{
Mark Sterling Gesell \\ College of William \& Mary - Arts \& Sciences
}

Follow this and additional works at: https://scholarworks.wm.edu/etd

Part of the Physiology Commons

\section{Recommended Citation}

Gesell, Mark Sterling, "The Hypothalamic-Hypophysial Neurosecretory System in the Iguanid Lizard, Dipsosaurus dorsalis: A Qualitative and Quantitative Study" (1971). Dissertations, Theses, and Masters Projects. Paper 1539624721.

https://dx.doi.org/doi:10.21220/s2-mg8y-0n95

This Thesis is brought to you for free and open access by the Theses, Dissertations, \& Master Projects at W\&M ScholarWorks. It has been accepted for inclusion in Dissertations, Theses, and Masters Projects by an authorized administrator of W\&M ScholarWorks. For more information, please contact scholarworks@wm.edu. 
The hypothalamic-hypophysial neurosecretory system in the iguanid lizard, Dipsosaurus dorsalis: A qualitative and quantitative study.

\author{
A Thesis \\ Presented To \\ The Faculty of the Department of Biology \\ The College of William and Mary in Virginia
}

In Partial Fulfillment

of the Requirements for the Degree of

Master of Arts

By

Mark S. Gesell

1971 


\section{APPROVAI SHEET}

This thesis is submitted in partial fulfillment of the requirements for the degree of

$$
\text { Master of Arts }
$$
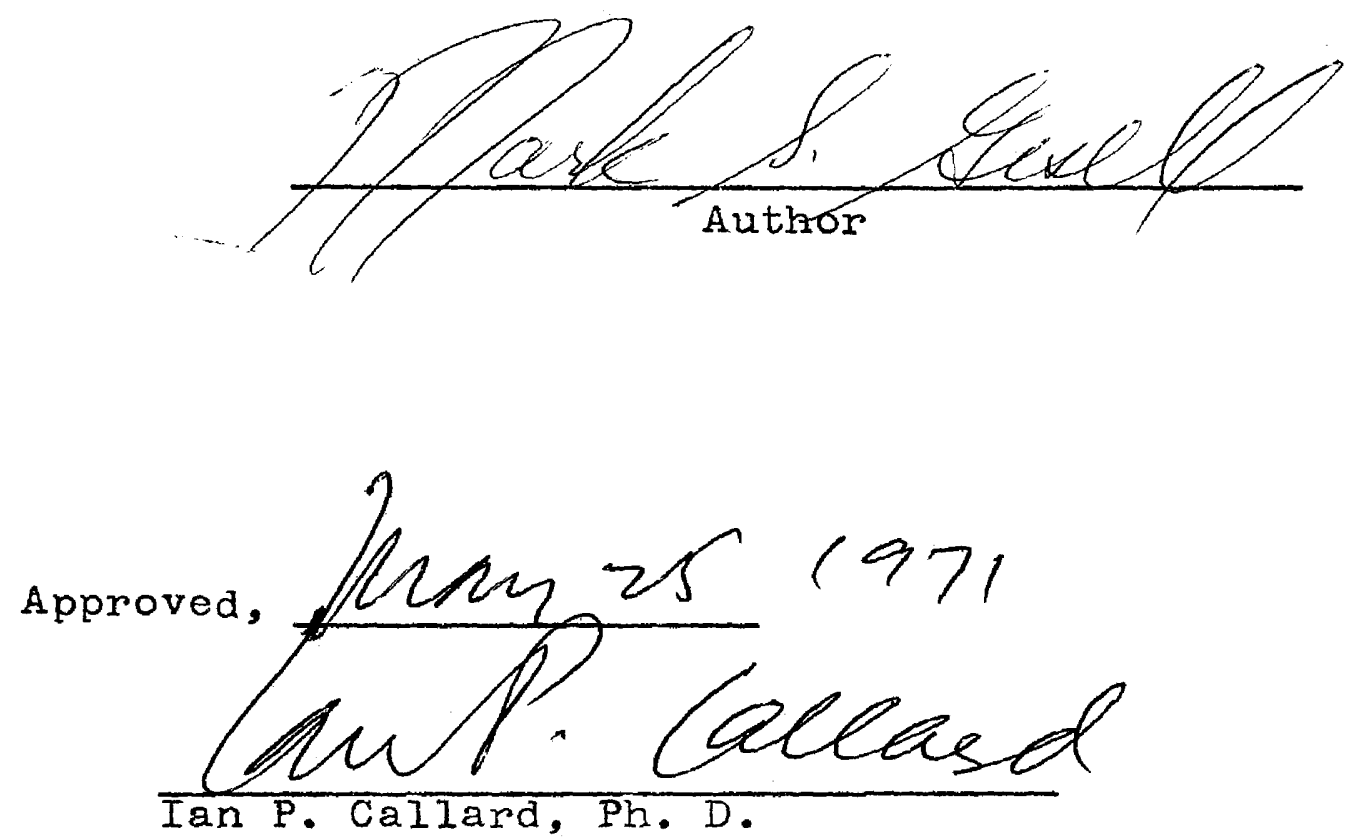

Canciote D. Manoun

Charlotte P. Mangum Ph. D.

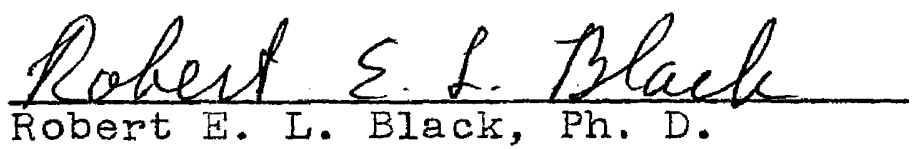

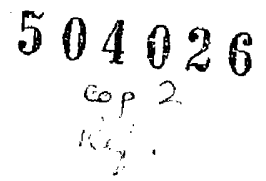

II 


\section{ACKNOWLEDGEMEITS}

Dr. Ian P. Callard, Dr. Charlotte P. Mangum, and Dr. Robert E. I. Black have generously offered aid and constructive criticism throughout the entire project and thus have made possible the completion of this work. Our association has been most pleasant and fortuitous for me.

My sister, Carol, has spent many hours translating my handwriting into legibility (a tiresome task at best) and deserves much credit for her efforts. Without the patience and understanding of my wife, Shoko, I could not have even begun this work. To all these people, a simple expression of gratitude is inadequate in view of all they have done. 
TABLE OF CONTENTS

$$
\text { Page }
$$

ACKNOWLEDGEMENTS. . . . . . . . . . . . . . III LIST OF FIGURES. • • . . . . . • . . . . . . V IIST OF PLATES. • • • • . • • • • • • • • • • . VI IIST OF TABLES. . . . . . . . . . . . . . . . VII ABSTRACT. . . . . . . . . . . . . . . . VIII INTRODUCTION. . . . . . . . . . . . . 2 MATERIALS AND METHODS. ............. 4 RESULTS. . . . . . . . . . . . . . 8 DISCUSSION. . . . . . . . . . . . . . 31 APPENDIX. . . . . . . . . . . . . 38 REFERENCES. . . . . . . . . . . . 53 


\section{IIST OF FIGURES}

Figure

Page

1. The Hypothalamic-Hypophysial Neurosecretory System of Dipsosaurus dorsalis . . . . . 15

2. Cellular Density Distribution Profiles

(frontal aspect of the brain) ...... 16

3. Cellular Density Distribution Profiles

(lateral aspect of the brain) . . . . . 17

4. Cellular Density Distribution Profiles

(3 dimensional) ............ . 18 


\section{LIST OF PLATES}

Plate

Page

1. Transverse section through the right paraventricular and right supraoptic areas showing the bridge of cells . . . .

2. Typical neurosecretory cell . . . . . . . 20

3. Section through the pars nervosa showing Herring bodies............... 21

4. Section through median eminence showing Herring bodies.............. . . . . 22

5. Transverse section through the median eminence.. 23

6. Longitudinal section through the median eminence. . . . . . . . . . . . 24

7. Transverse section through the pars nervosa... 25

8. Longitudinal section through the median eminence, adenohypophysis, and pars nervosa. . . . 26

9. Longitudinal section through median eminence, adenohypophysis, and pars nervosa showing the blood portal system . . . . . . . 27 


\section{LIST OF TABLES}

Table

Page

1. Dimensions of Hypothalamic Neurosecretory Areas ..................... 28

2. Percentages of Round Cells in Sample Brains; Percentages of Round Cells in Completely Counted Brains . . . . . . . . . . 29

3. Nuclear dimensions and volumes in neurosecretory cells derived from (A) sample sections from 11 different brains (B) serial sections from a single brain... . . . . . . 30 


\section{ABSTRACT}

An investigation of the neurosecretory system of the desert iguanid Dipsosaurus dorsalis was undertaken using "neurosecretory" stains on sectioned and in situ brains.

The two paraventricular and two supraoptic neurosecretory centers send tracts to the median eminence from which they proceed to the posterior lobe of the pituitary. There are neurosecretory tracts running between the paraventricular and supraoptic centers at their anterior and posterior margins. Tracts from the four hypothalamic neurosecretory centers coalesce and form a common tract going to the median eminence. Additional tracts from the paraventricular centers proceed directly to the posterior lobe of the pituitary independently of the other tracts.

Sizes of the hypothalamic neurosecretory centers were determined. Numbers of cells involved in neurosecretion were determined as well as the sizes and volumes of the nuclei of the neurosecretory cells. 
The hypothalamic-hypophysial neurosecretory system in the iguanid lizard, Dipsosaurus dorsalis: A qualitative and quantitative study. 


\section{INTRODUCTION}

While the reptiles remain a neglected class with regard to the study of endocrine phenomena, a number of investigations of the reptilian neurosecretory system have appeared in the literature in recent years (Abdel-Messeih and Tawfik, 1963; Anathanarayanan, 1955; Hild, 1951; Ito, 1961, 1965; Murakami, 1963; Nayar and Pandalai, 1964; Oota, 1963; Pandalai, 1958, 1960, 1966; Pandalai and Sheela, 1969; Philibert and Kamemoto, 1965; E. Scharrer, 1951; Sheela and Pandalai, 1968). The present investigation extends the observations to include the iguanid lizard Dipsosaurus dorsalis, and attempts to make some quantitative observations related to cell types and numbers in the hypothalamic neurosecretory centers. This information will supply a basis from which to investigate the role of these structures in the control of adenohypophyseal function in Dipsosaurus.

Bern (1962) describes three criteria for determining whether a nervous structure is or is not neurosecretory:

1. The finding of stainable materials in neurons-cytoplasmic inclusions in the forms of droplets, granules or vacuoles--regardless of the stain employed, only allows the conclusion that such neurons are possibly neurosecretory.

2. If...evidence of a secretory cycle can be adduced, based on the same kind of cytological criteria used in judging 
the secretory activity of an epithelial cell, then it is possible to conclude that such neurons are probably, but not necessarily, neurosecretory.

3. If the signs of secretory activity can be related to the production of chemical agents with measurable physiologic effects, agents definable as hormones, then it can be concluded that such cells are definitely neurosecretory.

This investigation will provide information which satisfies Bern's first criterion and which is essential to any investigations attempting to satisfy the other two criteria. 
MATERIALS AND METHODS

Female Dipsosaurus dorsalis were obtained from Southwestern Herpetological Research and Sales, Calimesa, California. They were maintained in the laboratory in 1.86 square meter enclosures on a bedding of Sanicel. Lettuce and water were supplied ad Iibitum. A temperature gradient within the enclosure ranging between $46^{\circ} \mathrm{C}$ and $21^{\circ} \mathrm{C}$ was provided and a 16 hour light-8 hour dark lighting cycle was used. Animals were maintained in the enclosures for two weeks prior to sacrifice. All animals were reproductively inactive as judged by gonadal size and appearance. In total, brains from 45 animals were used for sectioning and in situ techniques.

After removal of the lower jaw and the front portion of the snout, all heads were fixed in $10 \%$ buffered neutral formalin (Appendix I) for two days. The skin and as much of the musculature as possible were removed and the skull was decalcified in Evans and Kajian decalcification solution (Appendix II). After the skulls were decalcified, the brain was dissected out and thoroughly rinsed in water to remove the decalcification solution. Postmordanting in Bouin's fixative (Appendix I) followed the water rinse. To remove the picric acid the brains were rinsed in daily changes of 
$70 \%$ ethanol until as much of the yellow color of the picric acid as possible leached out--this took not less than one week.

Those brains to be sectioned were dehydrated and infiltrated with paraffin via a dioxane-parafin procedure (Appendix III). The entire brain was serially sectioned at $10 \mu$ in either the transverse or longitudinal plane. Sections, floated on a gelatin water bath, were affixed to slides and dried at $38^{\circ} \mathrm{C}$ on a slide warmer overnight. Sections were stained with Gomori's aldehyde-fuchsin as used by Halmi (1952), Gabe (1953), and Cameron and Steele (1959), and further modified by the author, or Gomori's chrome hematoxylin, (Gomori 1941), or the modified PASAlcian blue method of Heath (1965), and modified by the author (Appendix IV).

Those brains chosen for in situ examination of the neurosecretory system were stained with the modified aldehyde fuchsin methods of Dogra and Tandan (1964), and Leatherland (1968) or the Victoria blue method of Braak (1962) as used by Leatherland (1968) (Appendix V). After visual examination of the brains, some were embedded in plastic (Appendix VI) for further examination and photography.

\section{NUCLEAR COUNTS AND MEASUREMENTS}

1. Completely Counted Brain

The cellular nuclear dimensions in sectioned material were determined with a calibrated ocular micrometer disc. 
The sample size, mean and standard error were calculated for the individual hypothalamic cellular nuclei on one brain in which every cell appearing neurosecretory was counted. This brain is designated the completely counted brain.

Density distribution profiles based on the numbers of cells found in each $10 \mu$ section of each hypothalamic nucleus of two completely counted brains were constructed as an aid in visualizing the contours of the hypothalamic nuclei and as an aid in determining the most suitable area from which to sample subsequent brains.

\section{Sample Brains}

By determining the antero-posterior or most lateral limits of the hypothalamic nuclei in sectioned material in 16 brains, dimensions for the overall size of the hypothalamic centers were obtained and are reported along with standard error.

From 11 brains, cell nuclei were counted and measured in representative sections. The section used was chosen on the basis of the distance to a dense portion of the hypothalamic area from a peripheral limit as measured in the completely counted brain and seen in the cellular density distribution profile.

\section{CALCULATIONS AND STATISTICS}

The percentages of round and oval nuclear types in sections were calculated. Differences among nuclear type 
percentages in hypothalamic centers in the transverse and longitudinal planes were determined by use of Wilcoxon's Two Sample Test.

From the measured nuclear dimensions, the nuclear volumes were calculated using the formulae for a regular sphere and a prolate spheroid. The sample size, mean, and standard errors were calculated for the completely counted brain and the sample brains. 


\section{RESULTS}

I. GENERAL DESCRIPTION OF THE NEUROSECRETORY. NUCLEI AND TRACTS

(Figure 1, Plates 1-9)

The supraoptic centers are very flat sheets of cells closely applied to the surface of the diencephalon on either side of the midline of the brain. Some cells extend anterodorsaliy along the surface of the diencephalon a short distance up the cleft between the diencephalon and telencephalon. From this area cells extend caudally toward the paraventricular center where they intergrade with cells extending rostrally from the anterior margin of the paraventricular center forming a bridge of cells between the two areas ( $f i g .1, A$ and plate 1 ).

Anterior to the optic chiasm, there is a protuberance of the diencephalon which is relatively dense with neurosecretory cells (fig. 1). Immediately caudal to this protuberance and coincident with the anterior margin of the optic chiasm, cells of the supraoptic center extend dorsocaudally and laterally toward the paraventricular center where they intergrade with cells extending from the caudal. margin of the paraventricular center ventrally, rostrally, and laterally forming a second bridge between the two areas (fig. 1,B). 
Cells also are found immediately dorsal to the optic stalk along the surface of the brain. Cells of the supraoptic center extend along the surface of the diencephalon with the greater cell density medially and lesser density lateraliy.

Most cells of the supraoptic center are closely applied to the surface of the brain, giving this center the appearance of being compressed into a thin sheet although some cells extend into the mass of the brain a short distance. The paraventricular centers are ovoid masses of cells on either side of the third ventricle. The centers are most dense toward the third ventricle and caudally, and taper off laterally and rostrally. In lateral aspect, the centers are oval with the major axis diagonal to the antero-posterior plane of the brain with its anterior end more ventral than its posterior end. From the anterior margin of this center, cells extend rostrally and ventrally where they intergrade with cells extending from the anterior margin of the supraoptic center to form a bridge of cells (fig. 1, A and plate 1). At the posterior margin of the paraventricular center, cells extend anteriorly, laterally, and ventrally where they intergrade with cells extending from a posterior area of the supraoptic center forming a second bridge of cells (fig. I,B).

In both the supraoptic and paraventricular centers, the situation found on one side of the midline of the brain is mirrored on the opposite side of the midline of the brain. 
The neurosecretory cells of the hypothalamus typically contain a large nucleus with a prominent nucleolus. The cell body may send out elongate axonal processes which are often branched. In adition, it may also possess a dendrite. Granules stainable by "neurosecretory" stains are found throughout the cytoplasm of the cyton and its processes. The degree of granulation varies from extremely dense to extremely sparse. The processes characteristically are beaded in appearance. (plate 2)

The neurosecretory cells send processes toward the area of the hypophysis forming the hypothalamo-hypophysial tract. Neurosecretory tracts (II) extend from the supraoptic center along the ventral surface of the diencephalon and turn toward the midline just posterior to the optic chiasm where with tracts from the supraoptic center of the opposite side of the brain they form a common tract (I) which extends on to the median eminence. From the anterior margin of the paraventricular center, neurosecretory tracts (III) extend anteriorly before turning posteriorly to run along with the tracts from the supraoptic center already described (II). Tracts (IV) also extend laterally from the paraventricular center and then turn postero-ventrally to join tracts from the supraoptic nucleus at a point near the posterior limit of the optic chiasm. The three tracts (two paraventricular and one supraoptic) then coalesce and turn medially to meet the tracts from the hypothalamic centers of the opposite side of the brain to form a common tract (I) 
extending into the median eminence. Another tract (V) extends from cells in the paraventricular center posteriorly to enter the pars nervosa directly and ends there as Herring bodies (plate 3) without first entering the median eminence. The common neurosecretory tract (I) enters the median eminence where some neurosecretory axons terminate or loop down toward the blood vessels of the primary capillary plexus (plate 4) while the remainder proceed to the pars nervosa. In the median eminence some tracts stream ventrally (plates 5 and 6) while others proceed to the pars nervosa. Herring bodies are seen in the median eminence and the pars nervosa. Blood vessels entering the median eminence ramify to form the primary capillary plexus bringing the blood suppiy in close apposition to the neurosecretory material concentrated there. From here the blood vessels enter the adenophyophysis via the hypophyseal portal stalk where they ramify forming the secondary capillary plexus (plates 8 and 9). In the pars nervosa, great concentrations of neurosecretory material next to blood vessels are found within the walls of the three lobes of that organ (plate 7). The three lobes of the pars nervosa enclose three cavities but unite at their anterior and posterior limits to give the outward appearance of a solid organ. The three cavities of the pars nervosa communicate with the third ventricle. The pars nervosa is surrounded by the pars intermedia. 
II. DINENSIONS OF NEUROSECRETORY

CENTERS, NUCLEAR SIZES AND COUITTS

A. Overall Dimensions

Based on the assumption that the mean thickness of each section in the sectioned brains is $10 \mu$, dimensions of the hypothalamic centers were calculated (Table 1).

B. Cellular Density Distribution Profiles (Figures 2, 3 and 4)

On the basis of the numbers of cells counted in each of the complete brains, cellular density distribution profiles were constructed for each hypothalamic center. Such profiles are representative of the cellular distribution and overall physical structure of the hypothalamic neurosecretory centers of the brain. Observations of sectioned brains and brains stained by in situ techniques support this statement.

By referring to Figures 2,3 , and 4 , it can be seen that the supraoptic centers are most dense toward the median, anterior aspect of the brain and taper off toward the lateral and posterior margins of the center. The paraventricular centers are most dense toward the median, posterior aspect of the brain and taper off toward their lateral and anterior margins. The paraventricular centers are elongate in their antero-posterior axis while being comparatively compressed laterally (Figures 2, 3, and 4).

While this method of visualization affords a good overall view of the hypothalamic neurosecretory centers, it does not reveal the fine details of the morphology of 
the centers seen by direct observations of sectioned and in situ brains. The observations made and the insight into the general morphology of the hypothalamic centers afforded by the cellular density distribution profiles are borne out by the figures of the overall dimensions in Table 1 . The supraoptic centers, which are wider than long, appear as flattened sheets of cells closely applied to the surface of the diencephalon on either side of the midline of the brain. The paraventricular centers, which are longer than wide, appear as thin sheets of cells lateral to the third ventricle.

\section{Nuclear Counts and Measurements}

Total Number of Cells

AIl cells observed in each of the four neurosecretory centers from two serially sectioned brains were counted. From the figures in Table 2 , it can be seen that for these two brains the total number of cells within each neurosecretory area is remarkably similar.

\section{Nuclear Types}

In transverse and longitudinal sections in all brains examined, both round and oval nuclei were observed. Percentage values obtained from counts in two serially sectioned brains in which every neurosecretory celi was counted fall within the range found for the sample sections from 21 different brains. Further, values obtained from both transverse and longitudinal sections were not significantly different using Wilcoxon's two-sample test, and the two sets 
of data were combined to give single means and standard errors for all four neurosecretory areas (Table 2). The supraoptic areas consist predominantly of cells with oval nuclei and the paraventricular areas consist primarily of cells with round nuclei.

\author{
Nuc lear Volumes \\ Nuclear volumes were calculated assuming the round
} nuclei are regular spheres and the oval nuclei are prolate spheroids. Table 3 shows that in all instances the volumes of round nuclei are larger than those of oval nuclei; however, in the paraventricular areas the difference between the two nuclear types is less than in the supraoptic areas. For each neurosecretory area, mean nuclear volumes calculated from the serially sectioned brain in which all neurosecretory cell nuclei were measured are not significantly different from values calculated using representative sections from 11 brains. 


\section{Figure I}

The Hypothalamic-Hypophysial Neurosecretory System of Dipsosaurus dorsalis

P.V. Paraventricular Neurosecretory Center

S.O. Supraoptic Neurosecretory Center

0.C. Optic Chiasm

M.E. Median Eminence

P.V. Portal Vessel Stalk

P.D. Pars Distalis

P.I. Pars Intermedia

P.N. Pars Nervosa

IIIV. Third Ventricle

I-V Neurosecretory Tracts 


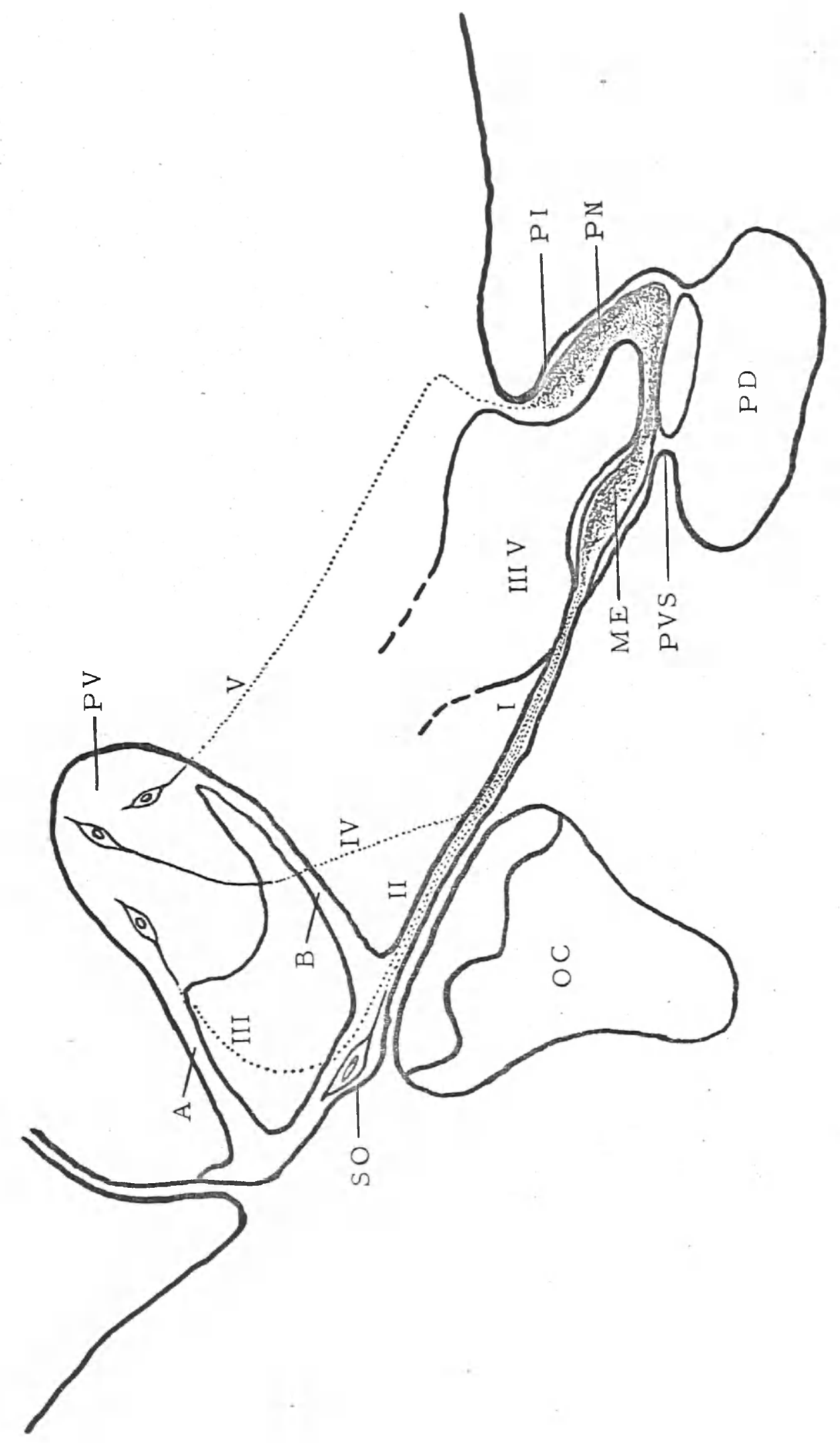


Figure 2

Cellular Density Distribution Profiles

(frontal aspect of the brain)

The profiles were obtained by plotting the number of neurosecretory cells found in each $10 \mu$ longitudinal section of brain tissue.
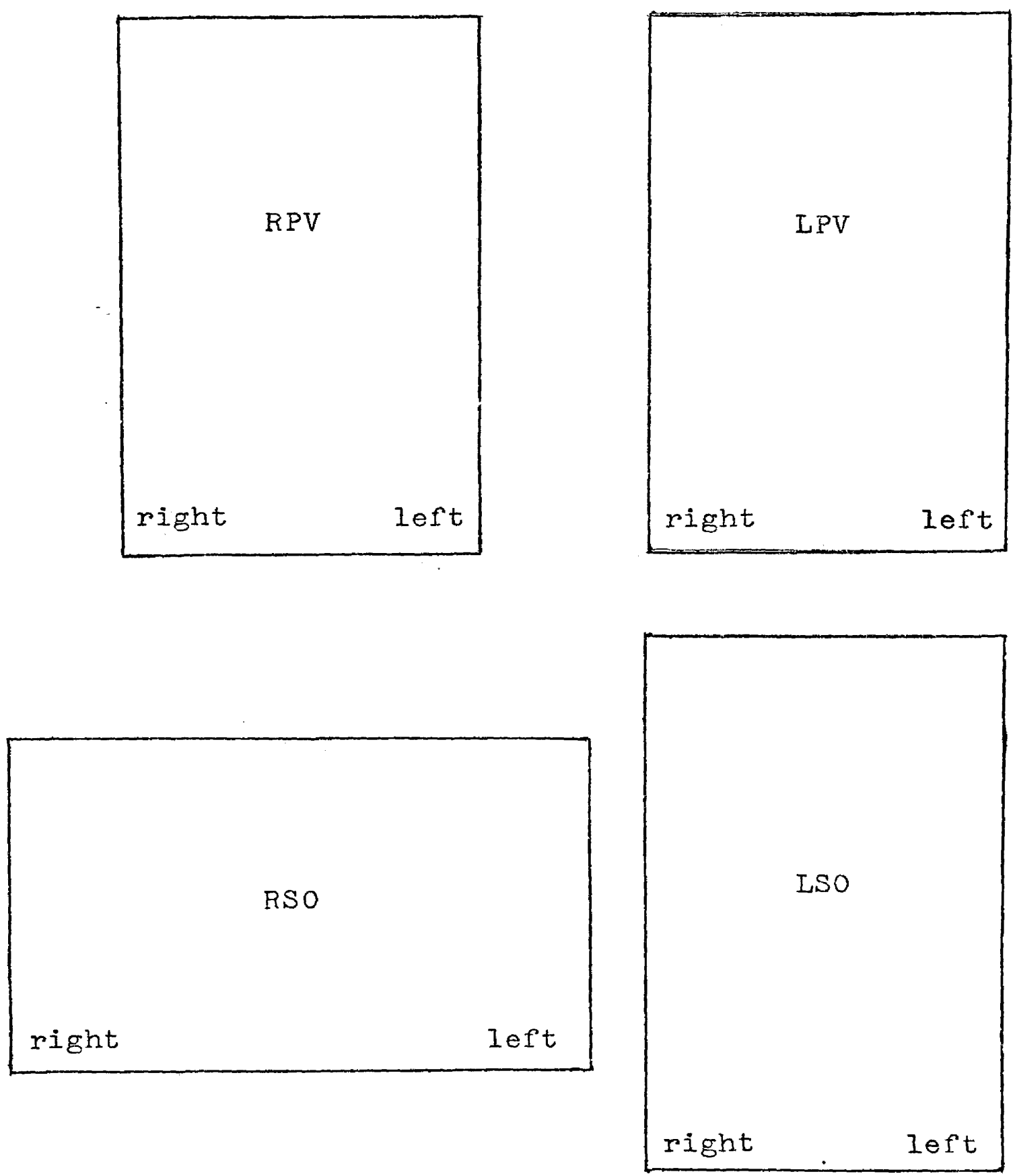

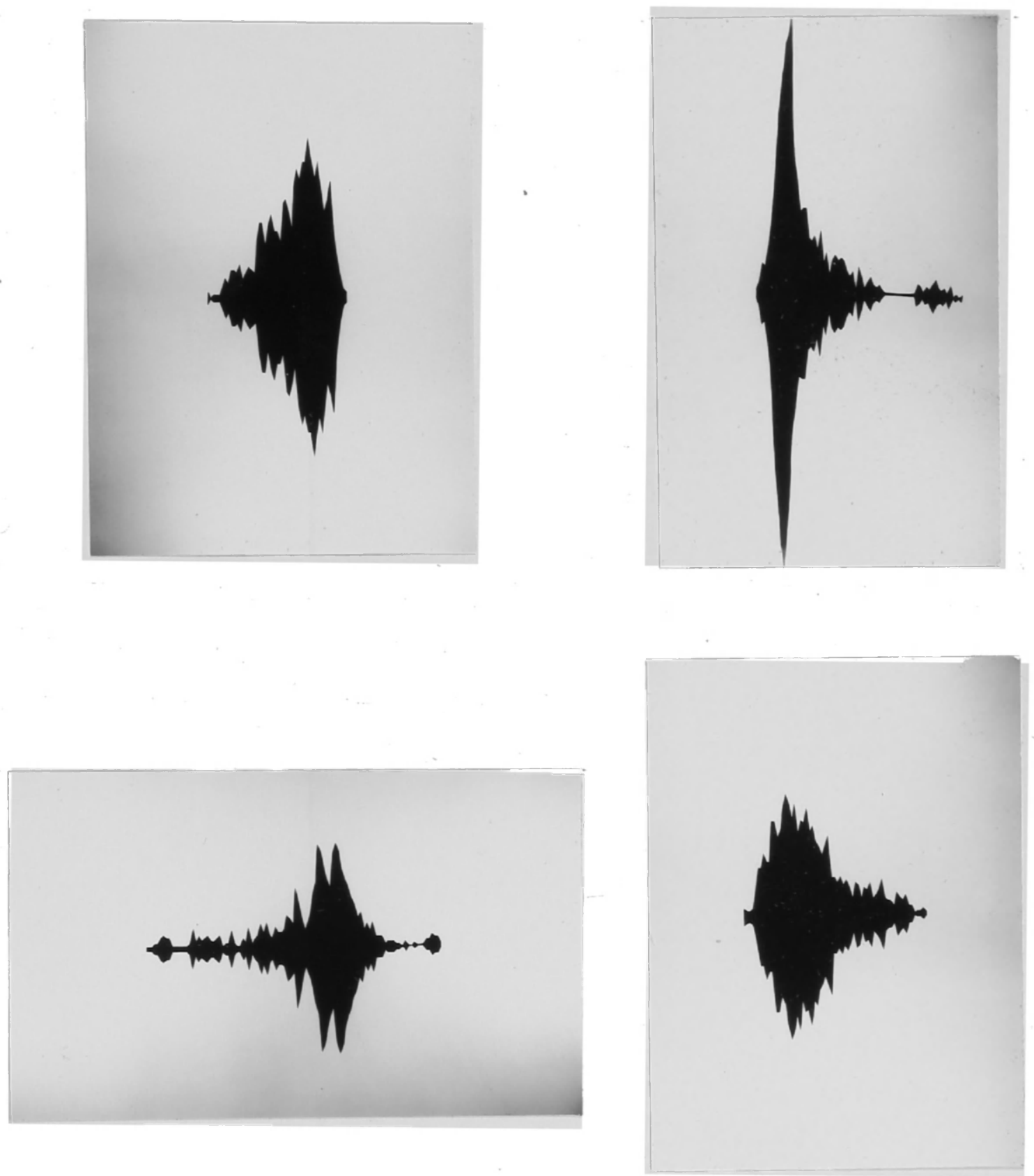

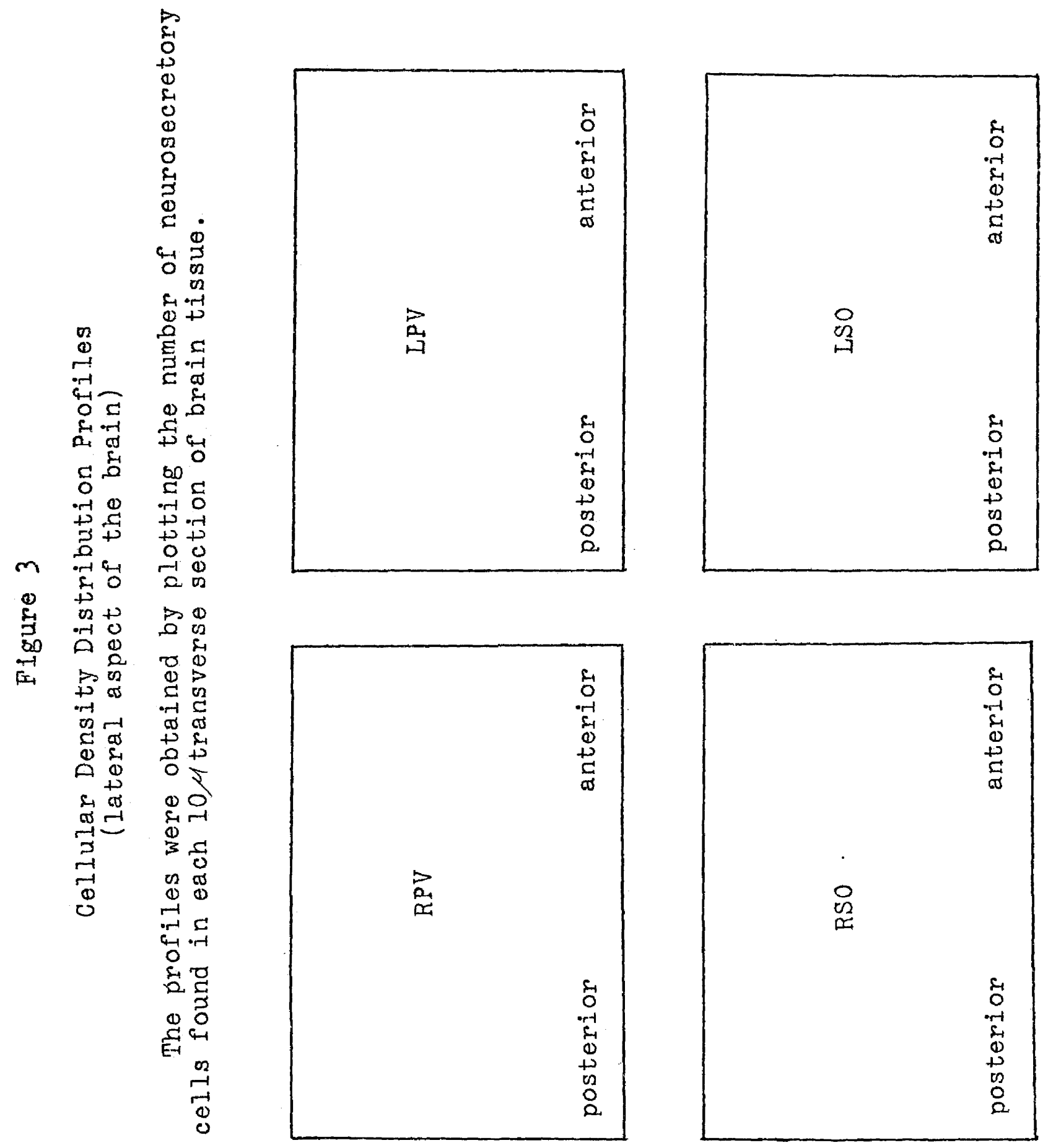

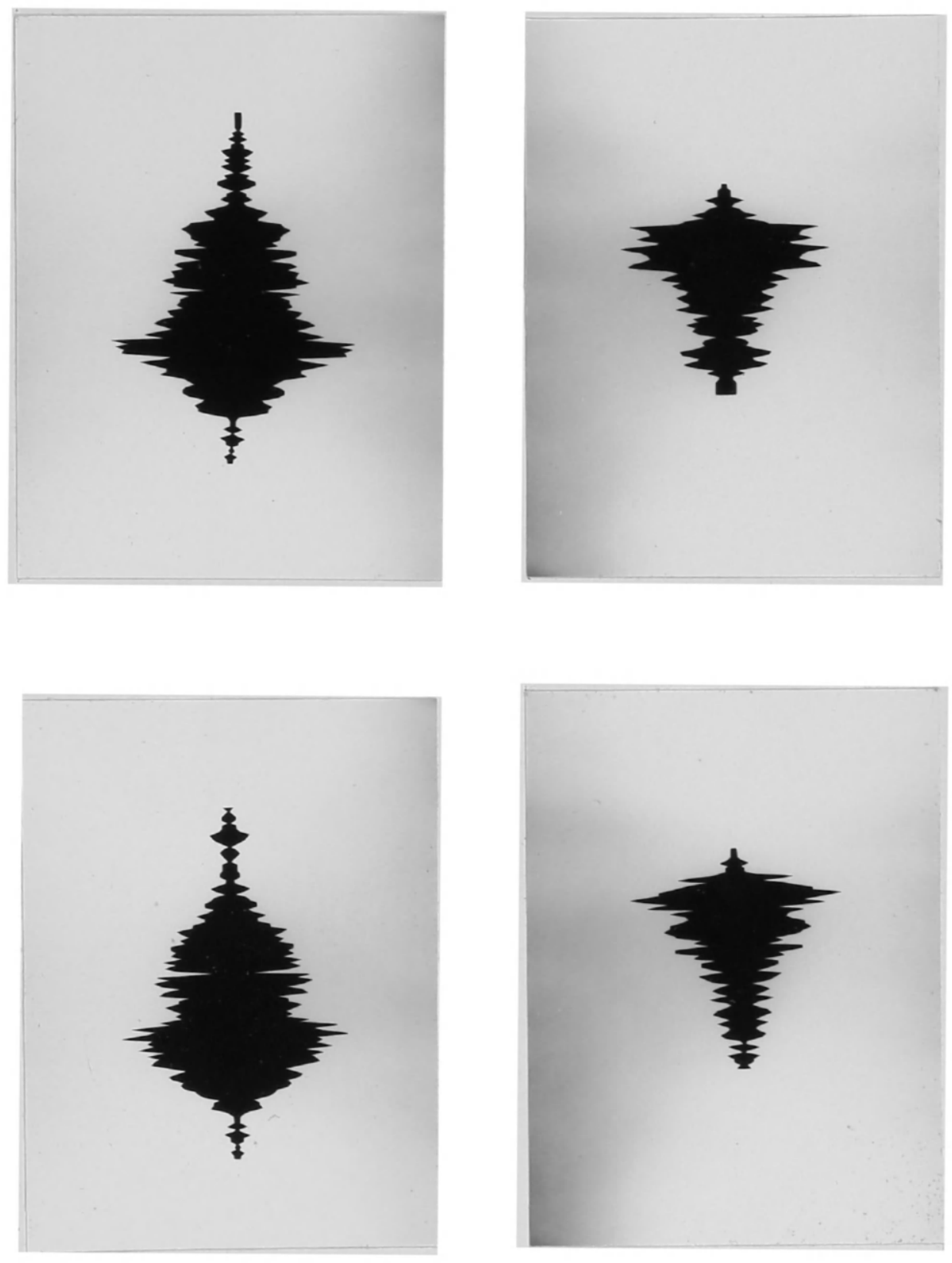
Figure 4

Cellular Density Distribution Profiles

( 3 dimensional)

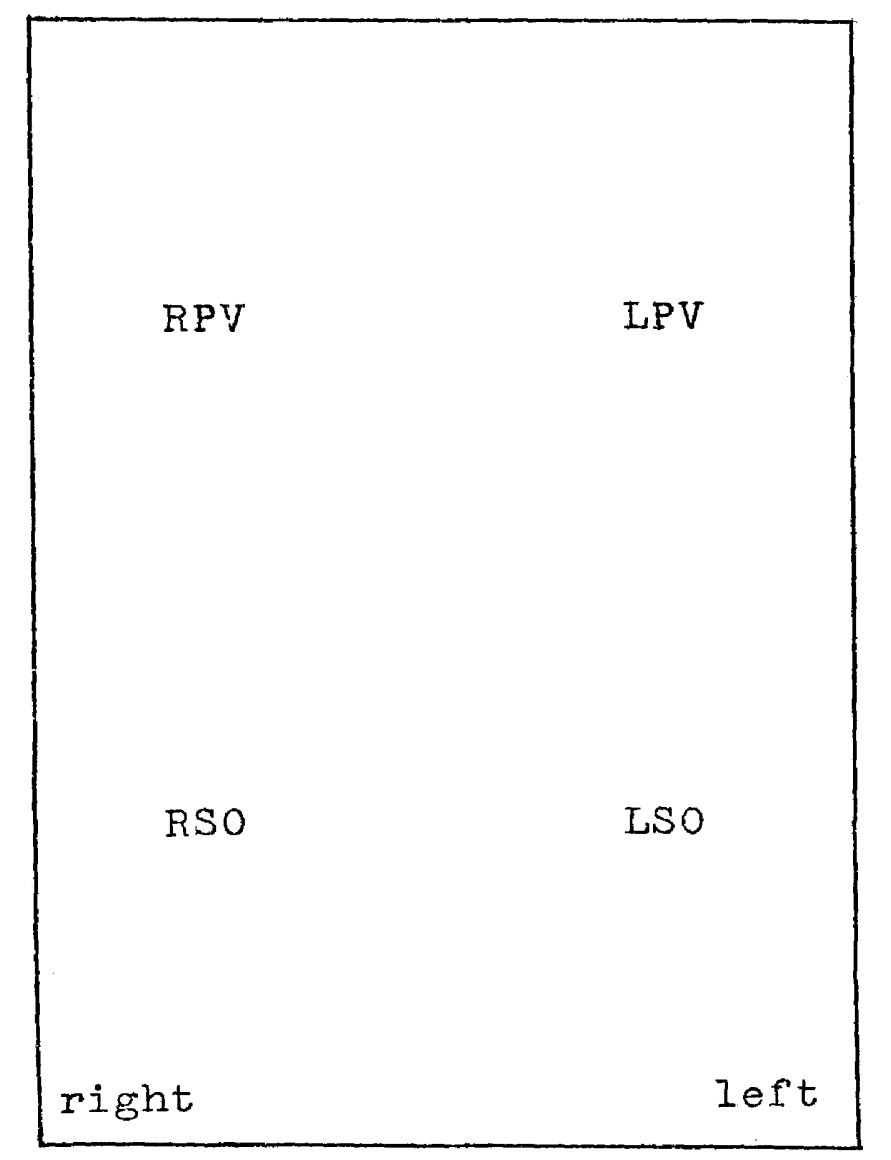

The darker images lie in the antero-posterior plane and the lighter images lie in the lateral plane. 


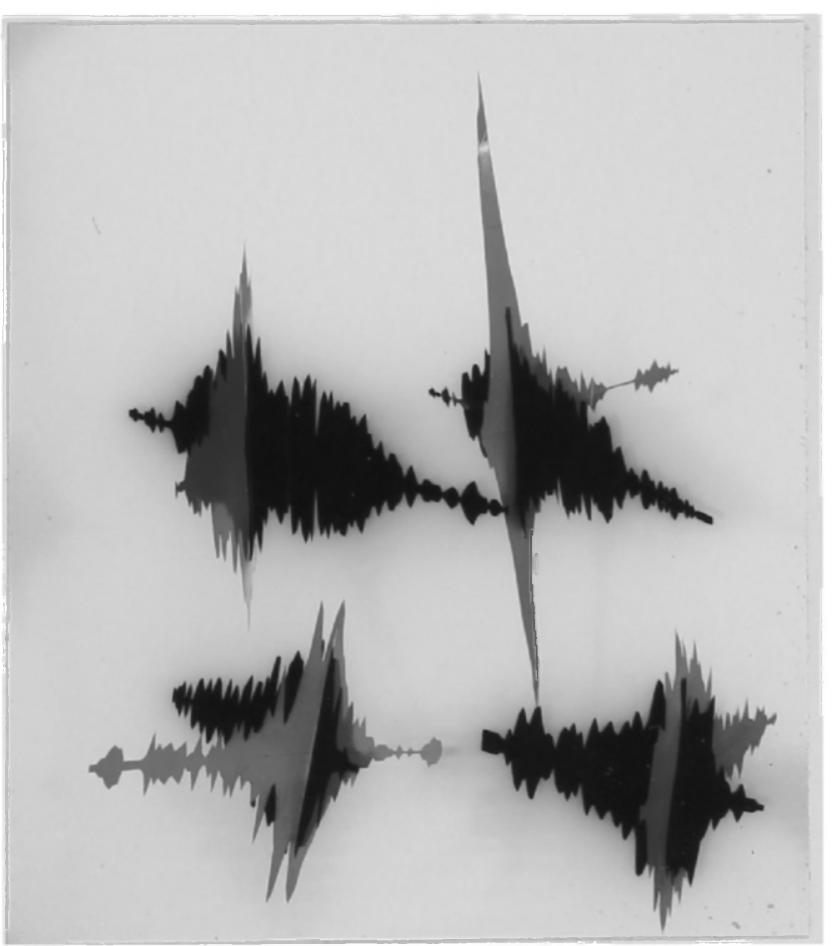




\section{Plate 1}

Transverse section through the right paraventricular and right supraoptic areas showing the bridge of cells. (Aldehyde fuchsin, $\mathrm{X} 160)$
III $V$ Third Ventricle
O C Optic Chiasm 


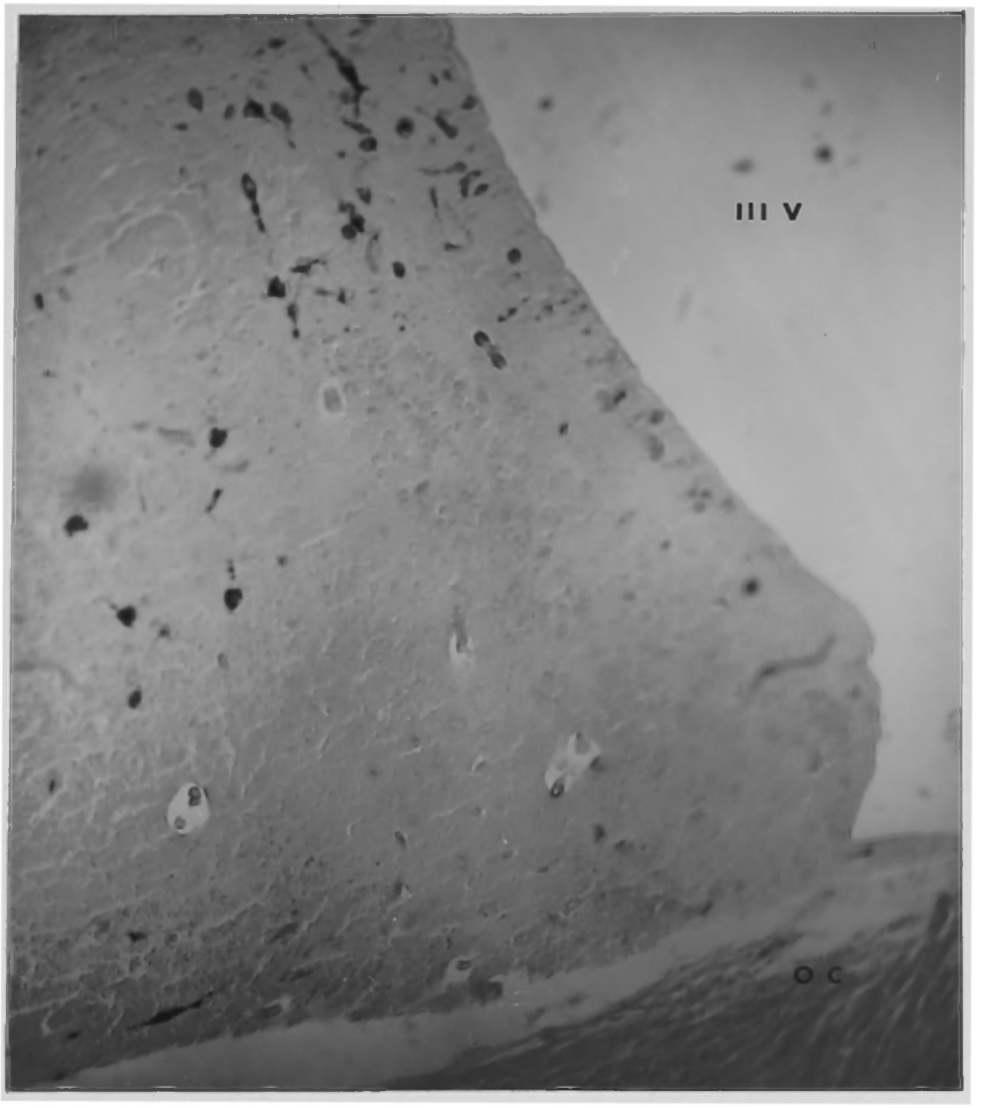


Plate 2

Typical neurosecretory cell. (Aldehyde fuchsin, $x 2000$ ) 


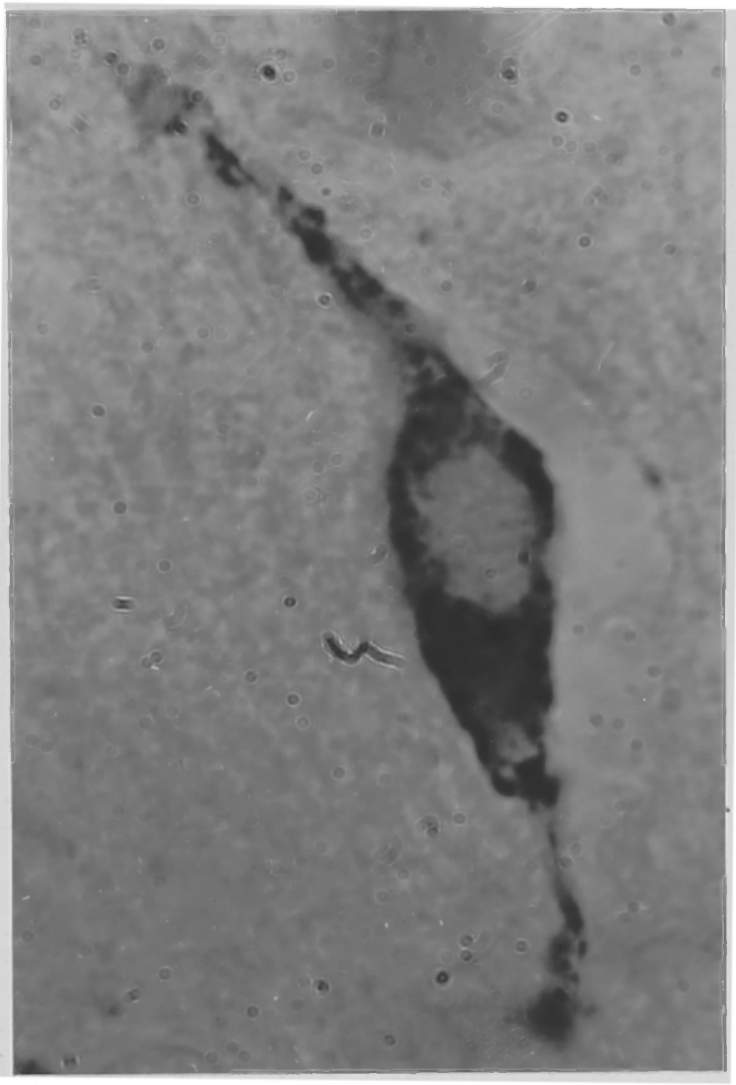




\begin{abstract}
Plate 3
Section through the pars nervosa showing
\end{abstract}

Herring bodies. (Chrome hematoxylin, X2000) 


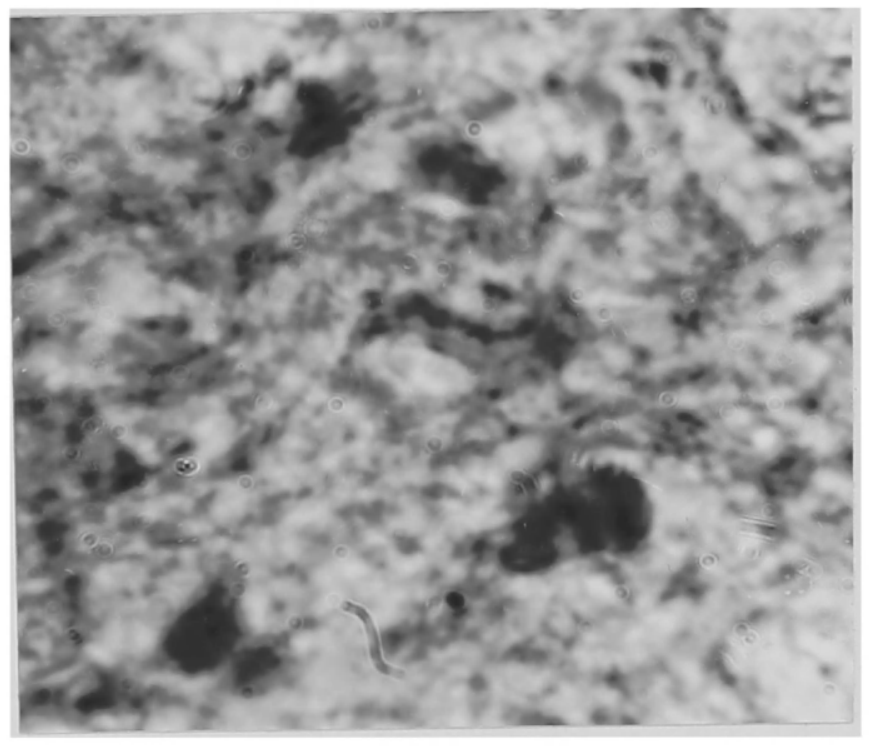




\begin{abstract}
Plate 4
Section through the median eminence showing Herring bodies. (Aldehyde fuchsin, X2000)
\end{abstract}




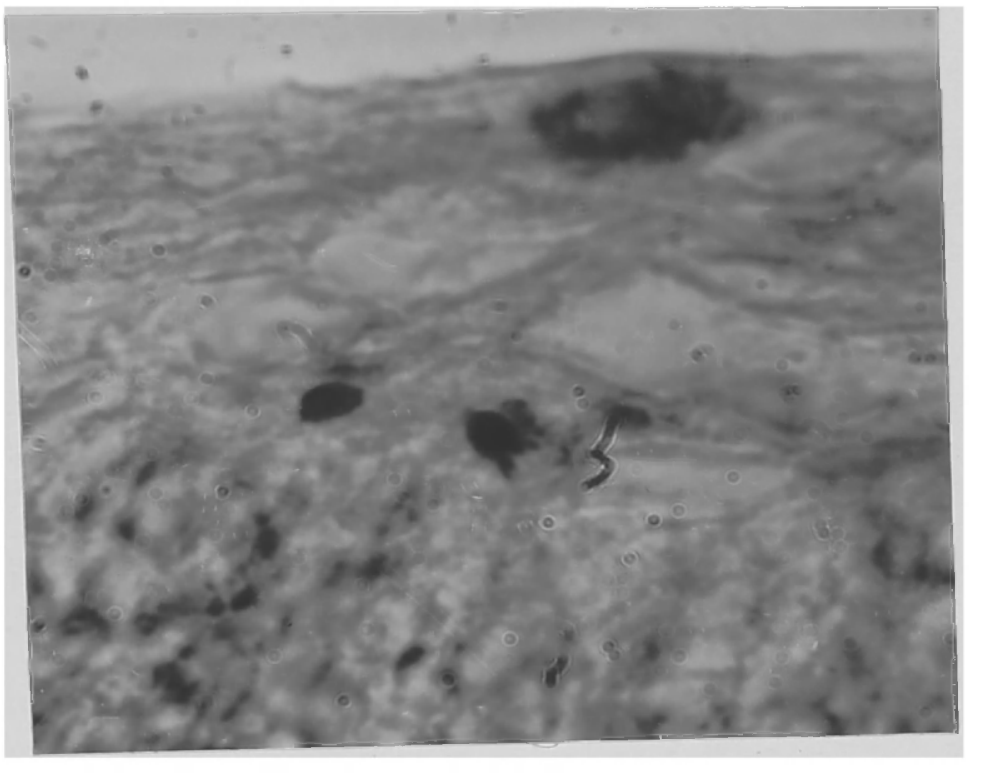


Plate 5

Transverse section through the median eminence exhibiting tracts of neurosecretory material. (Aldehyde fuchsin, XI60)

III $V$ Third Ventricle 


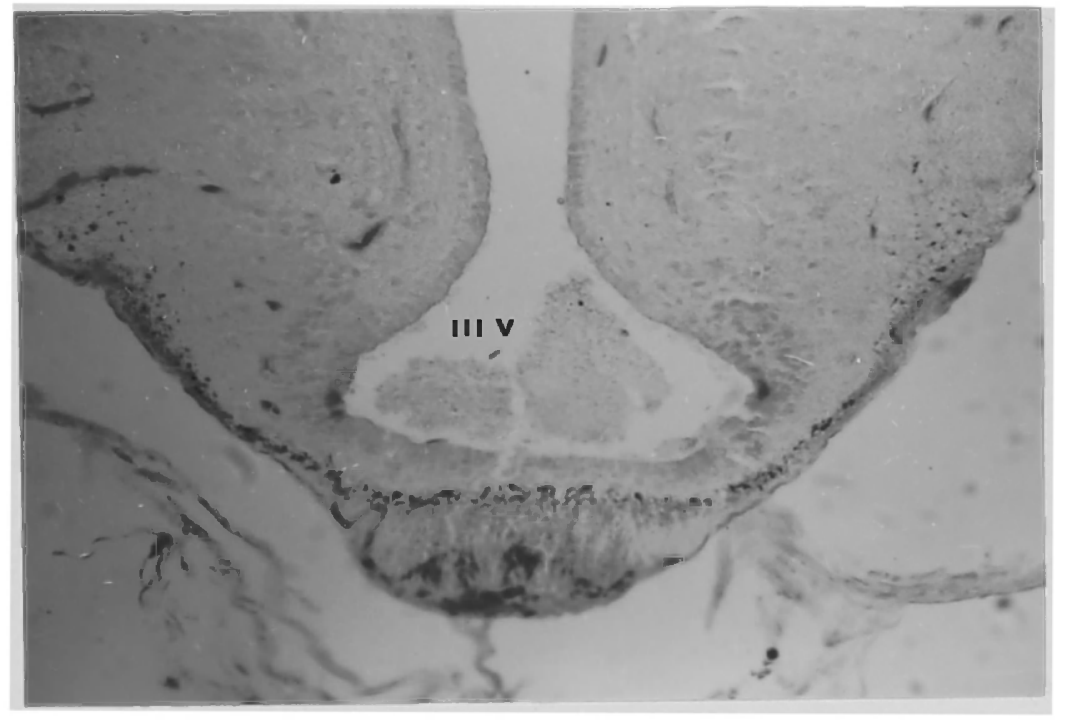




\section{Plate 6}

Longitudinal section through the median eminence exhibiting darkly stained neurosecretory material. (Aldehyde fuchsin, $\mathrm{X} 400$ ) 


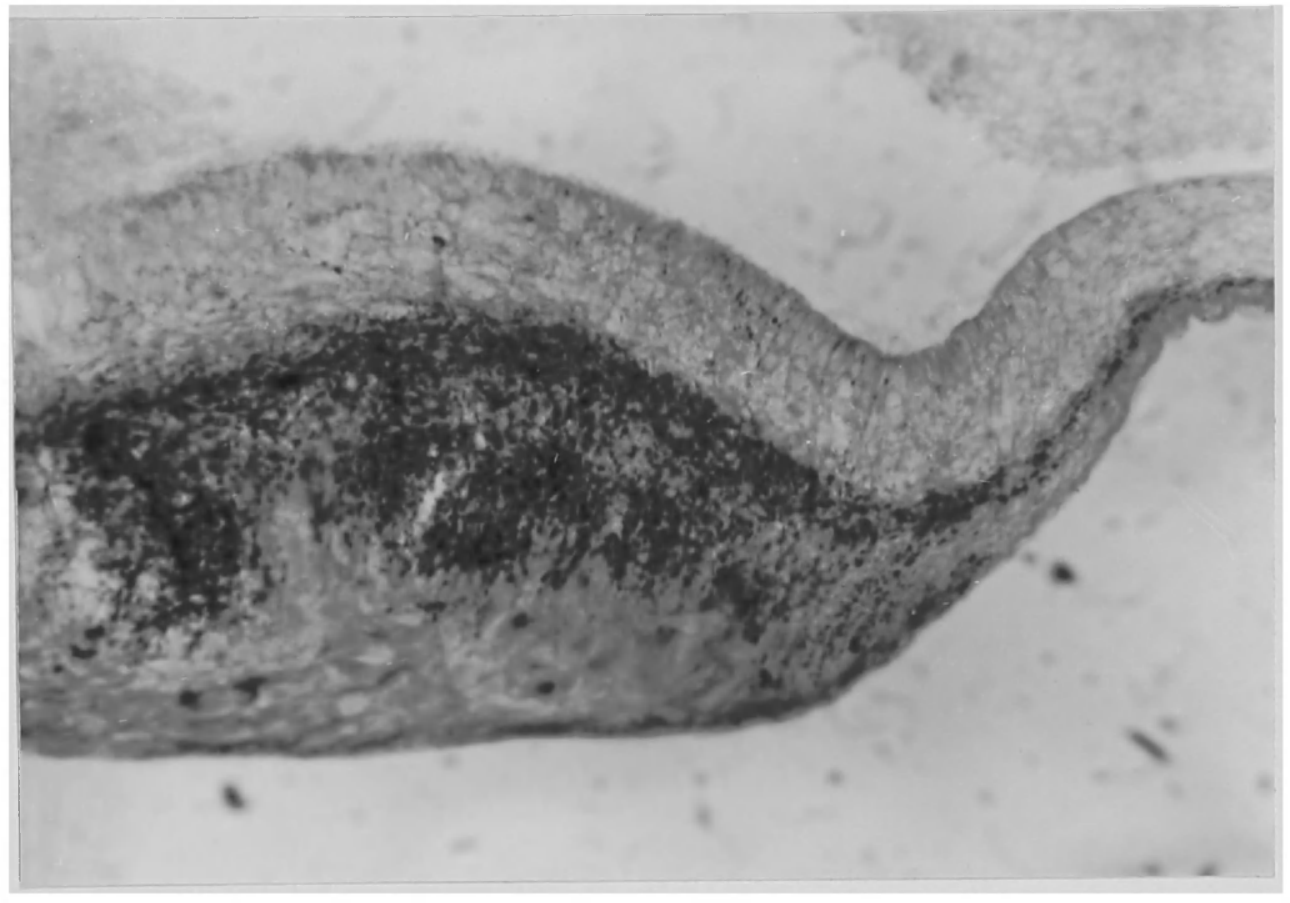




\section{Plate 7}

Transverse section through the pars nervosa showing the three lobes and the concentration of darkly stained neurosecretory material. (Aldehyde fuchsin, X160) 


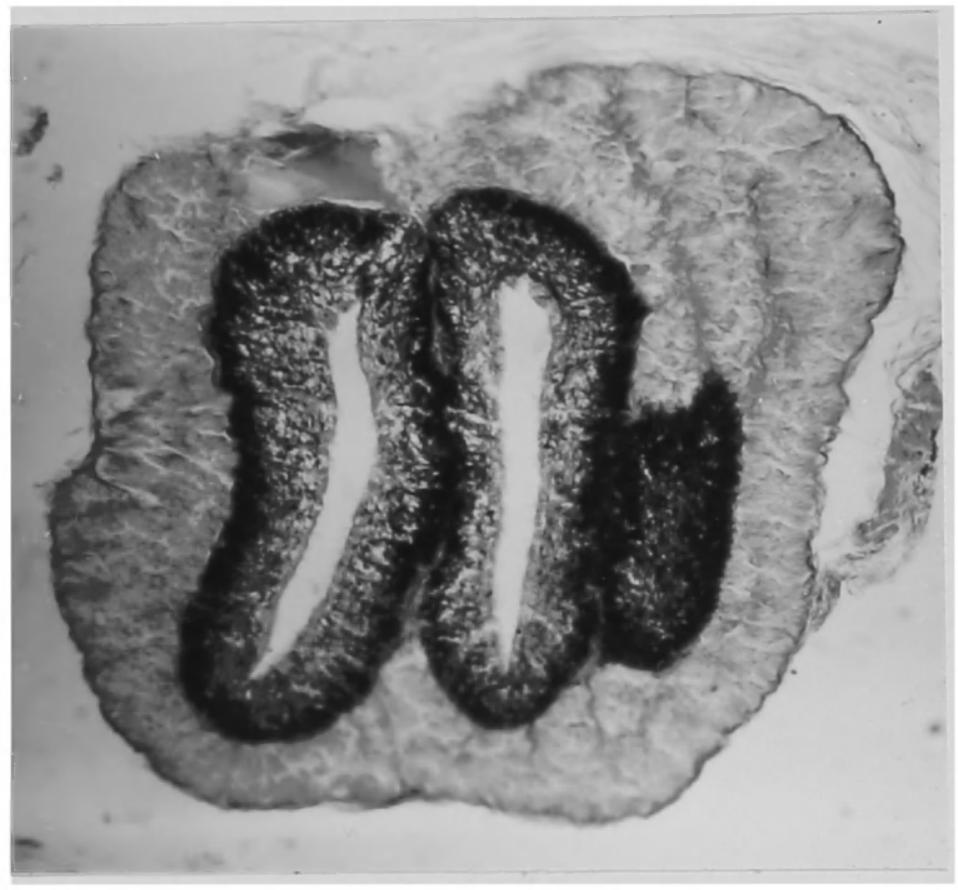


Plate 8

Longitudinal section through the median eminence, adenohypophysis, and pars nervosa. (Aldehyde fuchsin, X64)

$P$ N Pars Nervosa

M E Median Eminence

P V Portal Vessel Stalk

P D Pars Distalis

III $V$ Third Ventricle 


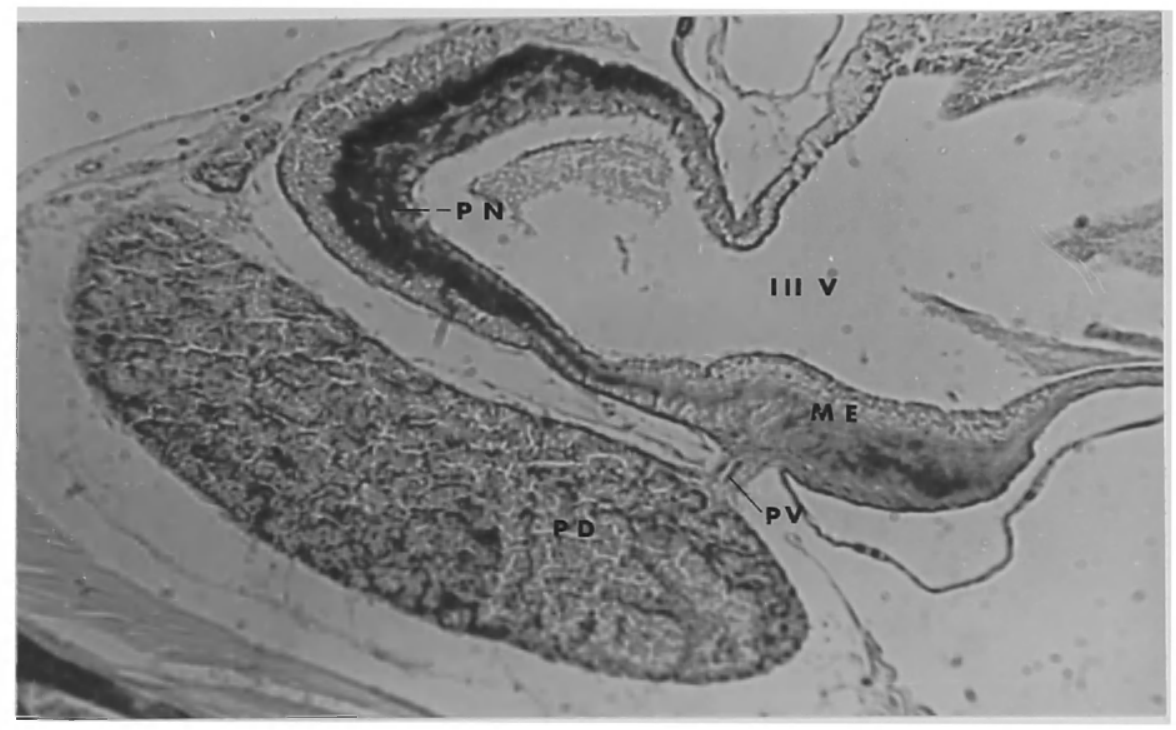


Plate 9

Longitudinal section through the median

eminence, adenohypophysis and pars nervosa

showing the blood portal system. (Chrome hematoxylin, XIO0)

P N Pars Nervosa

M E Median Eminence

P V Portal Vessel Stalk

$P$ D Pars Distalis

III $V$ Third Ventricle 


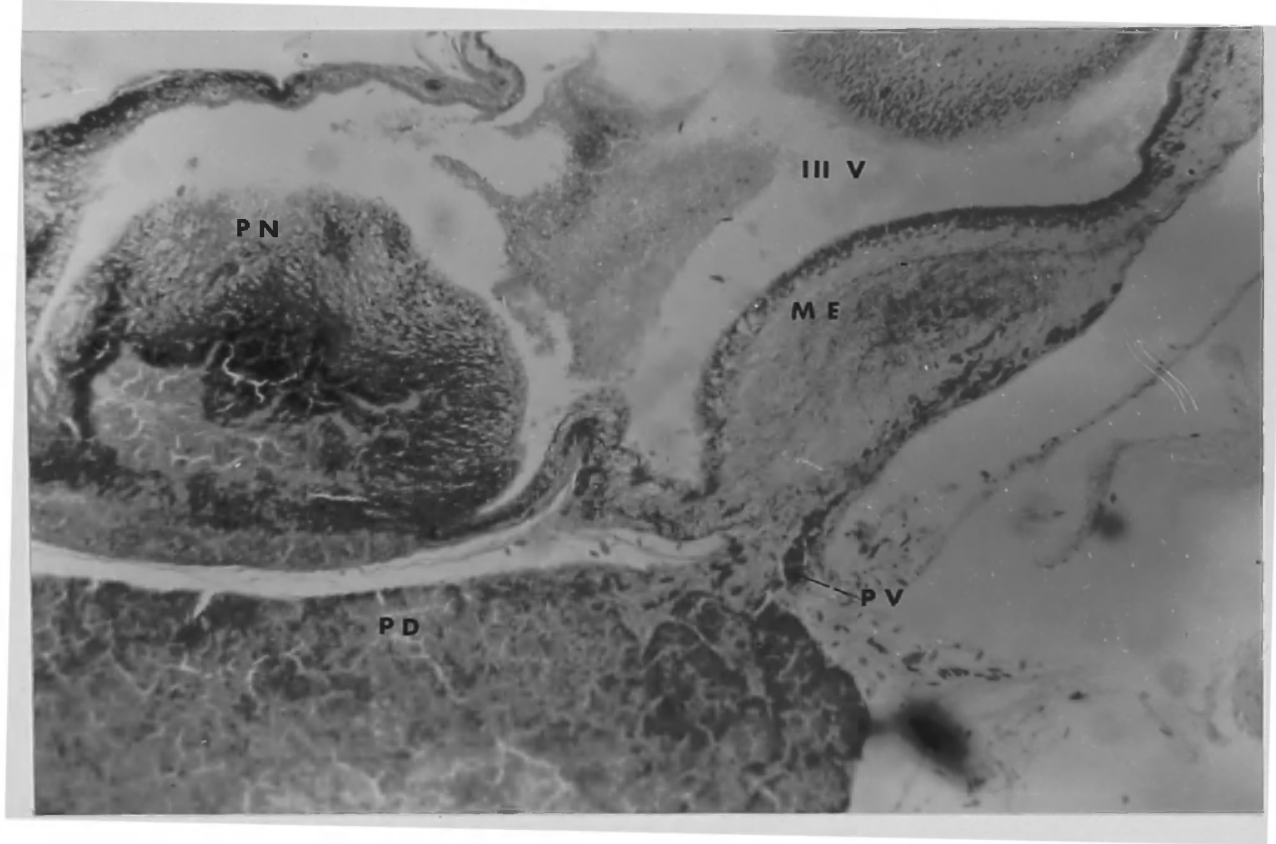


Table 1

Dimensions of Hypothalamic Neurosecretory Areas

\begin{tabular}{cccc}
\multicolumn{2}{c}{ RSO } & \multicolumn{2}{c}{ RPV } \\
length & width & length & width \\
$0.88 \pm 0.06$ & $1.04 \pm 0.02$ & $0.91 \pm 0.05$ & $0.56 \pm 0.05$
\end{tabular}

LSO

LPV

$\begin{array}{cccc}\text { length } & \text { width } & \text { length } & \text { width } \\ 0.86 \pm 0.06 & 0.92 \pm 0.04 & 0.93 \pm 0.04 & 0.55 \pm 0.07\end{array}$

The dimensions given (in mm.) are based on measurements of 16 brains. Length denotes the antero-posterior dimension and width denotes the lateral dimension of the hypothalamic area concerned.

RSO--right supraoptic area RPV--right paraventricular area LSO--left supraoptic area LPV--left paraventricular area 


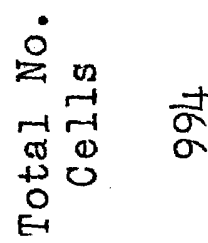

$\stackrel{r}{\sigma}$

$\stackrel{n}{\infty}$

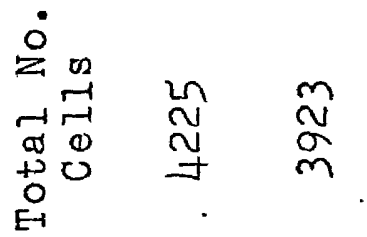

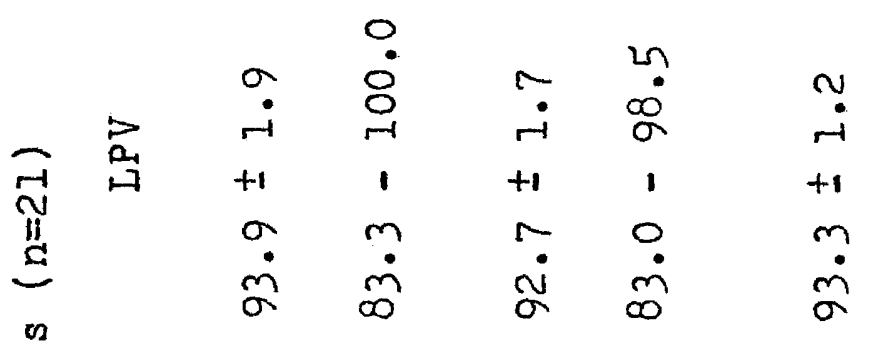

苗

ตั

$\begin{array}{llllll}0 & \sim & 0 & 0 & 0 & 0 \\ 0 & 0 & 0 & 0 & \sigma & r\end{array}$

0
+1
+1

$\begin{array}{llll}2 & m & 1 & 0\end{array}$

$\begin{array}{llll}\ddot{\sigma} & \dot{m} & \dot{0} & \ddot{0}\end{array}$

ri

กิ

$\stackrel{2}{-1}$

总

읍

出

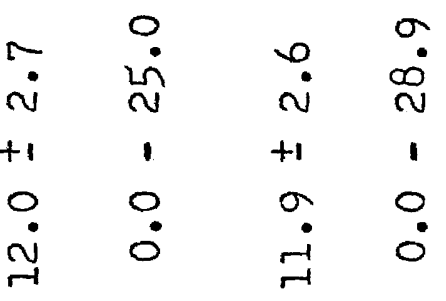

$\infty$
+1
+1
-1

0
0
60
$\pi$
+3
5
0
0
0
0
0.

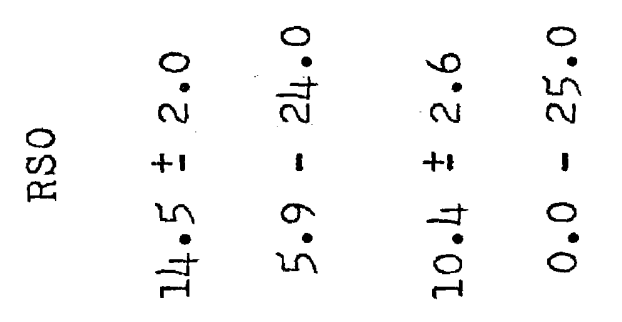

-1
+1
$m$

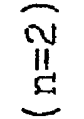

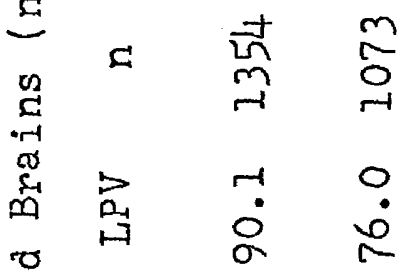

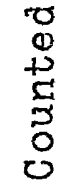

a $\stackrel{m}{\stackrel{m}{r}} \underset{r}{\stackrel{r}{0}}$

a $\quad \begin{array}{ll}m & 0 \\ 0 & \infty\end{array}$

.

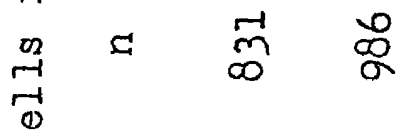

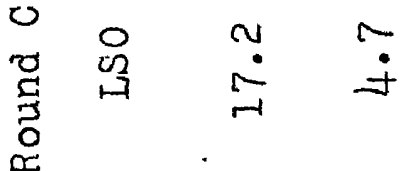

$\therefore \stackrel{r}{r}$

$\begin{array}{lll}0 & \infty & 0 \\ 0 & \stackrel{0}{N} & 0\end{array}$

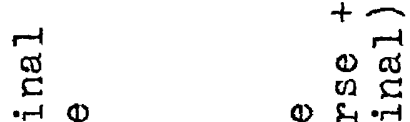

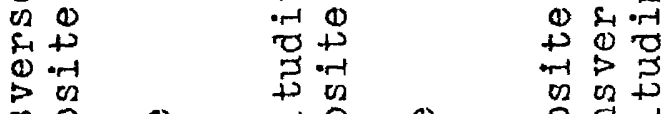

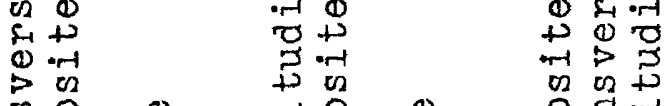

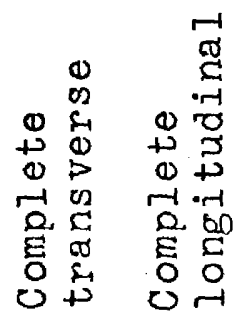




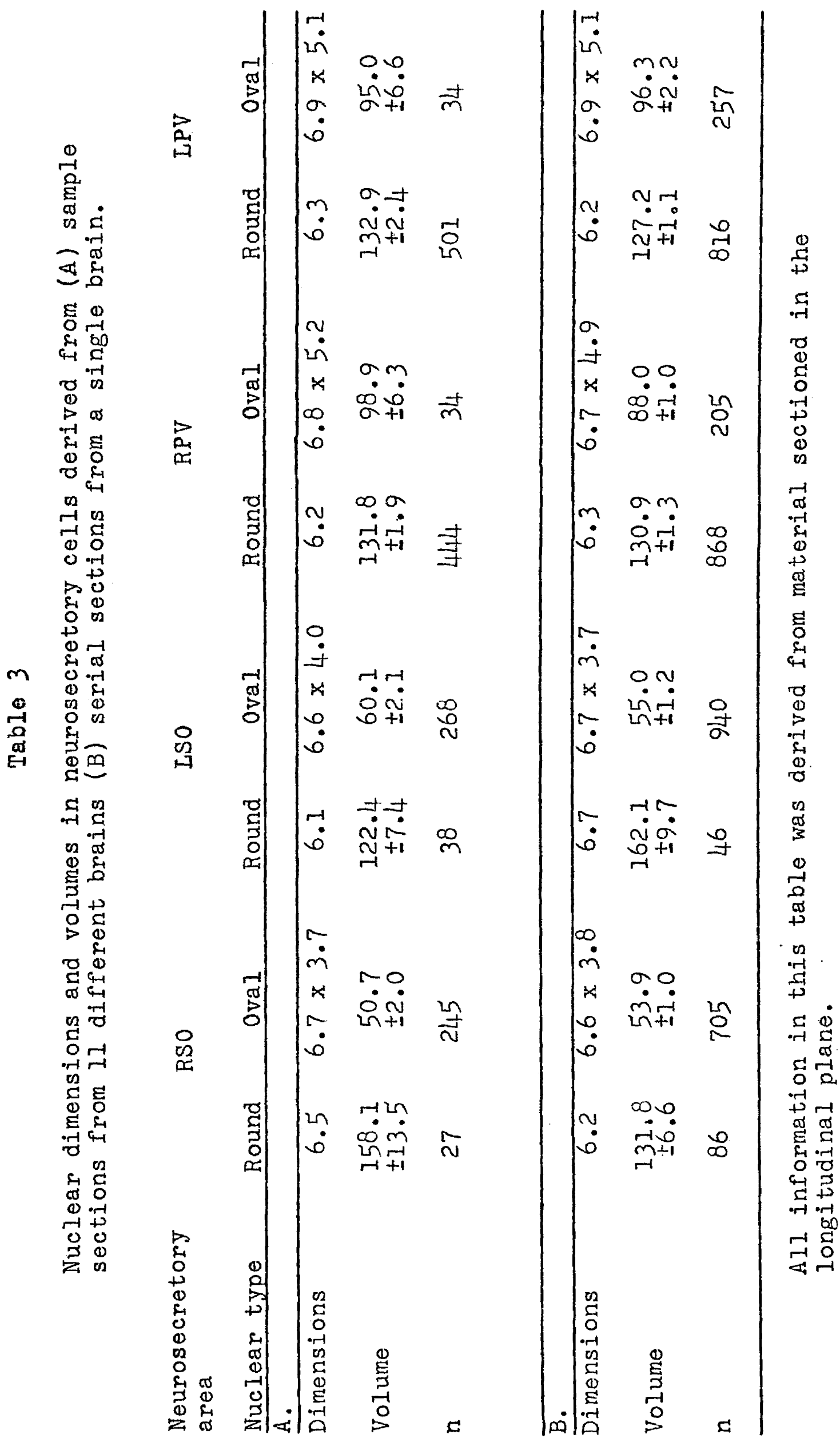




\section{DISCUSSION}

In Dipsosaurus dorsalis four hypothalamic neurosecretory centers (two paraventricular centers and two supraoptic centers) were identified. The centers on either side of the midline of the brain are interconnected by bridges of cells. Four neurosecretory tracts from cells in the hypothalamic centers coalesce anterior to the median eminence to form a common tract which proceeds through the median eminence to the pars nervosa. In the median eminence, the neurosecretory material streams ventrally toward vessels of the primary capillary plexus. These vessels travel via the portal stalk to the adenohypophysis where they ramify to form the secondary capillary plexus. Herring body structures were observed in the median eminence and the pars nervosa.

Measurements of overall dimensions of the hypothalamic neurosecretory centers, cellular density distribution profiles, and direct observations of sectioned and in situ material reveal that the supraoptic centers are flat sheets of cells along the surface of the diencephalon on either side of the midline of the brain and the paraventricular centers are thin, flat sheets of cells lateral to the third ventricle of the brain. The supraoptic centers are most dense medially, and taper off laterally and posteriorly; the paraventricular centers are most dense medially and posteriorly, and taper off laterally and anteriorly. 
Cellular counts indicate approximately 4,000 active neurosecretory cells in the brain of D. dorsalis, 1,200 cells in each paraventricular center and 800 cells in each supraoptic center. The numbers of neurosecretory cells found in the brain of D. dorsalis do not represent an absolute number but only the number of cells actively involved in neurosecretion under normal conditions as revealed by their staining reactions. Some cells resembling the neurosecretory cells in all details except that they did not exhibit the characteristic staining reaction were occasionally observed, indicating that there may be more neurosecretory cells than reported.

T'wo types of nuclei were identified in the neurosecretory cells examined. Most cells of the paraventricular areas have round nuclei while in the supraoptic region most cells have oval nuclei. Round nuclei are larger than oval nuclei and the round nuclei of the paraventricular areas are larger than those of the supraoptic region.

In subreptilian vertebrates, there is one hypothalamic neurosecretory area, designated the preoptic nucleus. In birds and mammals, there are two separate hypothalamic neurosecretory areas - the supraoptic and paraventricular. Philibert and Kamemoto (1965) report variations in the positions of cells of the hypothalamic nuclei in the ringnecked snake Diadophis punctatus which make the paraventricular and supraoptic centers appear to be continuous at points. Pandalai (1958, 1966) states that the supraoptic and paraventricular neurosecretory centers of lizards blend with each 
other just dorsal to the preoptic recess of the third ventricle. The condition in D. dorsalis is more than an occasional variation in the position of cells. It is possible that this may represent a transition stage between the single preoptic nucleus in subreptilian vertebrates and the two completely separate hypothalamic neurosecretory centers of birds and mammals. The description of the overall shape and position of the hypothalamic neurosecretory centers of $D$. dorsalis is similar to the description of these centers in various other reptiles (Ananthanarayanan, 1955; Pandalai, 1958, 1966).

The description of neurosecretory tracts in D. dorsalis follows the general description of reptilian tracts given by Ananthanarayanan (1955), Dodd and Kerr (1963), Gabe (1966), Green (1951), Hild (1951), and Pandalai (1966). The tracts from the hypothalamic centers which unite to form the common tract going to the median eminence and neurohypophysis are common to all generalized descriptions of reptilian neurosecretory systems. No hypothalamo-paraphysial tracts as observed in Thamnophis sp. (Scharrer, 1951), Sitana ponticeriana, and Calotes versicolor (Ananthanarayanan, 1955) were seen in D. dorsalis which is in accord with the findings of Pandalai (1966) that no extrahypothalamic neurosecretory cells exist in lizards. However, the tracts described here for D. dorsalis which go directly to the pars nervosa independently of other tracts have been described for this species only.

Neurosecretory material streaming ventrally to come in close apposition with blood vessels of the primary capillary 
plexus has been described in Diadophis punctatus (Philibert and Kamemoto, 1965), in Clemmys japonica (Oota, 1963), in Calotes versicolor (Nayar and Pandalai, 1964), and in birds (E. Scharrer, 1953; Farner and Oksche, 1962). Scharrer (1953) interprets this streaming as looping of the neurosecretory fibers while Farner and Oksche (1962) observe that neurosecretory fibers loop down toward the primary capillary plexus in some birds while in other birds the neurosecretory fibers in the median eminence terminate next to vessels of the primary capillary plexus. Nayar and Pandalai (1964) observe that the nerve fibers carrying the neurosecretory material in the median eminence loop down toward vessels of the primary capillary plexus in Calotes versicolor. The observations made in this investigation support previous descriptions of the anatomical relationships of the neurosecretory elements, the median eminence, the primary capillary plexus and portal vessels, and the adenohypophysis (Green, 1951; Green and Maxwel1, 1958). These observations add to the conviction that the neurosecretory elements are in some way involved in the control of the adenohypophysis in reptilia (Pandalai, 1958; Kobayashi and Matsui, 1969).

The paraventricular neurosecretory centers of Diadophis punctatus (Philibert and Kamemoto, 1965) and Varanus griseus (Abdel-Messeih and Tawfik, 1963) appear larger than the supraoptic neurosecretory centers, while in D. dorsalis the supraoptic neurosecretory center is larger than the paraventricular neurosecretory center, but contains fewer cells. 
Farner and Oksche (1962) report that more cells are present in the paraventricular than the supraoptic center in the bird Coturnix coturnix which agrees with the findings in D. dorsalis. While no cellular differences were observed in the neurosecretory regions in Diadophis punctatus (Philibert and Kamemoto, 1965), differences in cellular shape and size were observed in the bird Coturnix coturnix (Farner and Oksche, 1962). Five neurosecretory cell types have been recognized in Calotes versicolor (Pandalai, 1958). Of three "normal" cell types, two had round nuclei and the other possessed oval nuclei. In contrast, Murakami (1963) recognized only round nuclei in the supraoptic region of Gecko japonicus. In this investigation, both round and oval nuclei have been found in both supraoptic and paraventricular areas in D. dorsalis. Mean nuclear diameters of neurosecretory cells in both hypothalamic neurosecretory areas of seven reptiles (Ananthanarayanan, 1955) were larger than those of D. dorsalis. However, the findings of the latter author support those of the present investigation inasmuch as nuclei of paraventricular cells were found to be larger than those of supraoptic cells. While there is an indication of different cell types in the neurosecretory areas, the relationship of these cell types to different functional states of the same cell and to possible neural lobe principles in the reptilia is uncertain. A number of authors have attempted physiologic manipulations of reptiles in an effort to obtain responses of the neurosecretory elements which would help in the identification of 
different functional cell types. Abdel-Messeih and Tawfik (1963) correlated changes in neurosecretory cells with starvation (comparable to dehydration) and Pandalai (1960) observed alterations in neurosecretory cells in response to a variety of "stresses" (dehydration, temperature manipulation, blinding, and injection of male sex hormones). By the use of water stress experiments, Sheela and Pandalai (1968) and Philibert and Kamemoto (1965) have implicated the paraventricular region as the site of production of a vasopressor principle. However, Sheela and Pandalai (1968) also found involvement of the supraoptic area in response to a severe osmotic stress, suggesting different thresholds of response for different areas.

There is evidence (Sokol and Valtin, 1967) for the production of oxytocin and vasopressin in different cel is of the rat hypothalamus. Pandalai (1966) has noted differences in oxytocic and vasopressor content in the different neurosecretory areas in lizards. Since different cell types appear to predominate in one or other of the neurosecretory areas in D. dorsalis, it is possible that these cells are involved in the production of different neurosecretory principles, as suggested by Pandalai (1966). Two posterior lobe principles have been identified in snakes by Acher, et. al. (1969) who report that arginine vasotocin (8-arginine oxytocin) and mesotocin (8-isoleucine oxytocin) are the respective vasopressor and oxytocic principles in snakes 
and may be present in all reptiles. It remains for future work to elucidate the functional. cell types of the neurosecretory nuclei of reptiles and to relate their role to water and electrolyte balance and the control of the adenohypophysis. 


\section{APPENDIX I}

\section{Fixatives}

10\% Buffered Neutral Formalin

$37-40 \%$ formaldehyde

$100 \mathrm{ml}$

Sodium phosphate monobasic $\left(\mathrm{NaH}_{2} \mathrm{PO}_{4} \mathrm{H}_{2} \mathrm{O}\right)$

$4 \mathrm{gm}$

Sodium or potassium phosphate dibasic (anhydrous)

$\left(\mathrm{Na}_{2} \mathrm{HPO}_{4}\right)$ or $\left(\mathrm{K}_{2} \mathrm{HPO}_{4}\right)$

$6.5 \mathrm{gm}$

Distilled water

q.s. to $1000 \mathrm{mI}$

pH should be approximately 7

\section{Bcuin's Fixative}

Saturated aqueous picric acid ( $1.2 \%)$

$750 \mathrm{mI}$

$37-40 \%$ formaldehyde

$250 \mathrm{ml}$

Glacial acetic acid

$50 \mathrm{ml}$

Fix tissues in Bouin's fixative as little as 4 hours and no longer than 24 hours. Remove the picric acid from the tissues as completely as possible with frequent changes of $70 \%$ ethanol. 


\section{APPENDIX II}

\section{Decalcification}

\section{Evans and Kajian Decalcification Solution}

Solution A

Sodium citrate $\left(\mathrm{Na}_{3} \mathrm{C}_{6} \mathrm{H}_{5} \mathrm{O}_{7}\right)$

$20 \mathrm{gm}$

Distilled water

q.s. to $100 \mathrm{ml}$

Solution B

Formic acid $\mathrm{CHOOH}(90-98 \%)$

Distilled water
$50 \mathrm{ml}$

q.s. to $100 \mathrm{ml}$

To use mix equal quantities of solutions $A$ and $B$. Change the solution on the bone once daily until the bone is decalcified as determined by a decalcification test.

\section{Decalcification Test}

Sodium or ammonium oxalate $\sqrt{\mathrm{Na}_{2}} \mathrm{C}_{2} \mathrm{O}_{4}$ or $\left(\mathrm{NH}_{4}\right)_{2} \mathrm{C}_{2} \mathrm{O}_{4} \mathrm{I} \quad 5 \mathrm{gm}$ Distilled water q.s. to $100 \mathrm{ml}$

To test mix $5 \mathrm{ml}$ of the decalcification solution used on the bone with $1 \mathrm{ml}$ of the decalcification test solution. The bone is decalcified when no precipitate forms on the addition of the oxalate test solution to the used decalcification solution. 


\section{APPENDIX III}

\section{Dehydration and Paraffin Infiltration}

After all fixatives have been removed, soak the tissues in $70 \%$ ethanol and process according to the following schedule:

1. Dioxane--1 hour

2. Dioxane--1 hour

3. Dioxane--I hour

4. Paraffin* $\left(56-58^{\circ} \mathrm{C}\right)--1$ hour

5. Parafin $\left(56-58^{\circ} \mathrm{C}\right)--1$ hour

6. Parafin, in vacuo $\left(56-58^{\circ} \mathrm{C}\right)--1$ hour

7. Orient and embed as desired.

Do not allow the tissue to remain in the paraffin for longer times nor at a higher temperature than that recommended above.

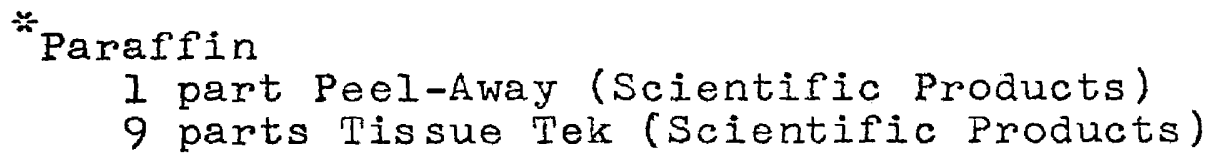




\section{APPENDIX IV}

Stains for Sections

All stains in this appendix are filtered immediately before use.

Gomori's Aldehyde Fuchsin (modified)

Halmi (1952), Gabe (1953), Cameron and Steele (1959)

1. Deparaffinize and hydrate sections

2. Oxidize in Gomori's oxidant

3. Rinse in water

4. Rinse in 5\% hypo until all the permanganate color is removed

5. Rinse in water

6. $70 \%$ ethanol

7. Stain in acidified aldehyde fuchsin

$10 \min$.

8. Rinse in $80 \%$ ethanol

9. Differentiate in acid alcohol

10. Rinse in water

11. Stain in Safranin 0

$5 \min$.

12. Briefly differentiate in acid alcohol

13. Rinse in water

14. Stain in modified Halmi's counterstain

$5 \min$.

15. Differentiate in acid alcohol very briefly 
16. Rinse in water

17. $80 \%$ ethanol

18. $95 \%$ ethanol (2 changes)

19. Absolute ethanol ( 3 changes)

20. Xylene (3-4 changes)

21. Mount in Permount

\section{Gomori's oxidant}

Potassium permanganate $\left(\mathrm{KM}_{n} \mathrm{O}_{4}\right) \quad 1 \%$ aqueous solution

Sulfuric acid

$1 \%$ aqueous solution

To use mix equal parts.

\section{Hypo}

Sodium thiosulfate $\left(\mathrm{Na}_{2} \mathrm{~S}_{2} \mathrm{O}_{3}\right) \quad 5 \%$ aqueous solution

\section{Aldehyde Fuchsin stain}

Aldehyde fuchsin powder (no C.I.\#) (Chroma) $0.5 \mathrm{gm}$ $70 \%$ ethanol q.s. to $100 \mathrm{ml}$

Concentrated $\mathrm{HCl}$

$1 \mathrm{ml}$

Once acidified, the stain does not keep more than

2 or 3 days.

\section{Acid Alcohol.}

$70 \%$ ethanol

Concentrated $\mathrm{HCl}$ q.s. to $100 \mathrm{mI}$

$1 \mathrm{ml}$

Safranin 0

Safranin O (C.I. \#50240) (Fisher)

$0.01 \mathrm{gm}$

Glacial acetic acid

$0.01 \mathrm{ml}$

Distilled water

q.s. to $100 \mathrm{mI}$ 


\section{Modified Halmi's counterstain}

Chromotrope 2R (C.I. \#16570) (Matheson, Coleman \& BeII) 0.5 gm Orange II (C.I. \#15510) (Chroma)

$1.0 \mathrm{gm}$

Fast Green FCF (C.I. \#42053) (Fisher)

$0.2 \mathrm{gm}$

Phosphotungstic acid $\left.\mathrm{H}_{3} \sqrt{\mathrm{P}}\left(\mathrm{W}_{3} \mathrm{O}_{10}\right)_{4}\right] \cdot 14 \mathrm{H}_{2} \mathrm{O}$

$0.5 \mathrm{gm}$

Glacial acetic acid

$1.0 \mathrm{ml}$

Distilled water

q.s. to $100 \mathrm{mI}$ 


\section{Gomori's Chrome Hematoxylin (modified) (Gomori 1941)}

1. Deparaffinize and hydrate sections to distilled water

2. Mordant sections in Bouin's fixative 16 hours

3. Wash in tap water to remove picric acid 15 min.

4. Oxidize in Gomori's oxidant 1-1/2 min.

5. Remove the permanganate color with $5 \%$ hypo solution

6. Rinse in water to remove hypo

7. Stain in chrome hematoxylin 15 min.

8. Differentiate in acid alcohol

9. Blue in tap water

10. Stain in Phloxine B-Eosin $Y$ counterstain 5 min.

11. Rinse in distilled $\mathrm{H}_{2} \mathrm{O}$

12. Place in $5 \%$ phosphotungstic acid solution 1 min.

13. Rinse in tap water until section regains red color

14. Differentiate in $80 \%$ ethanol

15. Dehydrate in $95 \%$ ethanol (2 changes) and absolute ethanol ( 3 changes)

16. Clear in xylene ( $3-4$ changes)

17. Mount in Permount

\section{Bouin's fixative}

Saturated aqueous picric acid $(1.2 \%) \quad 750 \mathrm{ml}$

$37-40 \%$ formaldehyde $250 \mathrm{ml}$

Glacial Acetic Acid $\quad 50 \mathrm{ml}$ 


\section{Gomori's oxidant}

Potassium permanganate $\left(\mathrm{KMnO}_{4}\right)$ $1 \%$ aqueous solution Sulfuric acid $1 \%$ aqueous solution

To use mix equal parts.

Hypo

Sodium thiosulfate $\left(\mathrm{Na}_{2} \mathrm{~S}_{2} \mathrm{O}_{3}\right)$ $5 \%$ aqueous solution

\section{Gomori's chrome hematoxylin}

Hematoxylin (C.I.\#75290) (Chroma) $1 \%$ aqueous solution $50 \mathrm{ml}$ Chromium potassium sulfate $\left(\mathrm{CrK}\left(\mathrm{SO}_{4}\right)_{2} \cdot 12 \mathrm{H}_{2} \mathrm{O}\right)$ $3 \%$ aqueous solution $50 \mathrm{ml}$

Potassium iodate $\left(\mathrm{KIO}_{3}\right)$

$0.1 \mathrm{gm}$

Boil the above solution until a deep blue color. The stain may be used immediately upon cooling.

\section{Acid Alcohol}

$70 \%$ ethanol

concentrated $\mathrm{HCl}$

$$
\text { q.s. to } 100 \mathrm{ml}
$$

$1 \mathrm{mI}$

\section{Phloxine B-Eosin $Y$ counterstain}

Phloxine B (C.I. \#45410) (Fisher)

Eos in Y (C.I. \#45380) (Chroma)

Distilled water

\author{
$0.4 \mathrm{gm}$ \\ $0.1 \mathrm{gm}$ \\ q.s. to $100 \mathrm{ml}$
}




\section{PAS-Alcian BIue (Heath 1965)}

1. Deparaffinize and hydrate sections to water

2. Oxidize sections in performic acid $5 \min$.

3. Rinse in water $10 \mathrm{~min}$.

4. Stain in Alcian blue $1 \mathrm{hr}$.

5. Rinse in water $10 \mathrm{~min}$.

6. Oxidize in Paraperiodic acid $5 \min$.

7. Rinse in distilled water

8. Place in Schiff's reagent $10 \mathrm{~min}$.

9. Rinse in tepid running tap water $10 \mathrm{~min}$.

10. Counterstain in Orange G-phosphotungstic acid

$1 \min$.

11. Rinse in acetic acid solution 30 sec. -1 min.

12. Dehydrate through 95\% ethanol (2 changes) and absolute ethanol ( 3 changes)

13. Clear in xylene ( $3-4$ changes)

14. Mount in Permount

Performic acid

Hydrogen peroxide $\left(30 \% \mathrm{H}_{2} \mathrm{O}_{2}\right) \quad 10 \mathrm{ml}$

Concentrated sulfuric acid

$1 \mathrm{mI}$

Concentrated formic acid $(90-98 \% \mathrm{CHOOH}) \quad$ q.s. to $100 \mathrm{ml}$ Use extreme care in handling this solution.

Alcian Blue

Alcian Blue BGX (C.I. \#74240) (Chroma)

$4 \mathrm{gm}$

Sulfuric acid, $4 \mathrm{~N}$

q.s. to $100 \mathrm{ml}$ 
Paraperiodic acid

Paraperiodic acid $\left(\mathrm{H}_{5} \mathrm{IO}_{6}\right) \quad 0.5 \%$ aqueous solution

\section{Schiff's Reagent}

Dissolve $1 \mathrm{gm}$ basic fuchsin (C.I. \#42510) (Chroma) in $200 \mathrm{ml}$ distilled water and heat to boiling. Cool and add $2 \mathrm{gm}$ potassium metabisulfite $\left(\mathrm{K}_{2} \mathrm{~S}_{2} \mathrm{O}_{5}\right)$ and $10 \mathrm{mI} \mathrm{IN}$ hydrochloric acid. Allow the solution to stand at room temperature in the dark for 24 hours. The solution should appear colorless to clear pale yellow. Add a quantity of activated charcoal and filter through a double thickness of highly retentive filter paper. Repeat addition of activated charcoal and filtration until the reagent is colorless. Store under refrigeration and do not reuse.

\section{Orange G-phosphotungstic acid}

Orange G (C.I. \#I6230) (K \& K Laboratories) Phosphotungstic acid $\mathrm{H}_{3}\left[\mathrm{P}\left(\mathrm{W}_{3} \mathrm{O}_{10}\right)_{4}-7.14 \mathrm{H}_{2} \mathrm{O}\right.$ Distilled water

\author{
$0.5 \mathrm{gm}$ \\ $1 \mathrm{gm}$ \\ q.s. to $100 \mathrm{ml}$
}

Acetic acid solution

$1 \%$ aqueous solution of glacial acetic acid 


\section{APPENDIX $V$}

\section{Stains for Whole Brain}

All stains in this appendix are filtered immediately before use.

\section{Modified Aldehyde Fuchsin (Dogra and} Tandan 1964), Leather land (1968)

1. Bring brain from $70 \%$ ethanol to distilled water

2. Oxidize brain in performic acid 2 hours

3. Rinse in 3 changes of distilled water $45 \mathrm{~min}$. each change 4. Rinse in 2 changes of $70 \%$ ethanol 30 min. each change

5. Stain in aldehyde fuchsin 2 hours

6. Differentiate using acid alcohol

7. Rinse in $80 \%$ ethanol

1 hour

8. Rinse in 2 changes of $95 \%$ ethanol

I hour each change

9. Dehydrate in 3 changes of absolute ethanol

I hour each change

10. Clear in methyl salicylate for examination

11. Embed in plastic

Performic acid

$30 \%$ hydrogen peroxide $\left(\mathrm{H}_{2} \mathrm{O}_{2}\right)$

Formic acid $(90-98 \% \mathrm{CHOOH})$
1 part 10 parts Mix the above and allow to stand 1 hour before using. Use extreme caution in handling performic acid! 


\section{A] dehyde fuchsin}

Aldehyde fuchsin (no C.I. \#) (Chroma)

$0.5 \mathrm{gm}$ $70 \%$ ethanol q.s. to $100 \mathrm{ml}$

Acetic acid $1 \mathrm{ml}$

Unacidified stain solution keeps indefinitely, but the acidified solution lasts only a short time. 
Victoria Blue (Leatherland 1968), (Braak 1962)

1. Bring brain from $70 \%$ ethanol to distilled water

2. Oxidize in performic acid

3. Remove performic acid in 3 changes of distilled water 45 min. each change

4. Stain in Victoria blue stain 4 hours

5. Differentiate stain by soaking in $70 \%$ ethanol until no more blue is leached out $24-48$ hours

6. Place in $80 \%$ ethanol 1 hour

7. Place in 2 changes of $95 \%$ ethanol 1 hour each change

8. Dehydrate in 3 changes absolute ethanol 1 hour each change

9. Clear in methyl salycilate for examination

10. Embed in plastic

\section{Performic acid}

$30 \%$ hydrogen peroxide $\left(\mathrm{H}_{2} \mathrm{O}_{2}\right)$

1 part

Formic acid $(90-98 \% \mathrm{CHOOH})$ 10 parts

Mix the above and allow to stand $I$ hour before using. Use extreme caution in handling performic acid! 


\section{Victoria blue stain}

Mix 2 gm Victoria blue 4 R (C.I. \#42563) (Chroma), $4 \mathrm{gm}$ resorcin, and $0.5 \mathrm{gm}$ dextrin in $200 \mathrm{ml}$ distilled water and heat. Add $25 \mathrm{ml}$ of $29 \%$ aqueous ferrous chloride $\left(\mathrm{FeCl}_{2}\right)$ solution which has been heated. After heating three more minutes, cool under running water and filter. Dry the precipitate at $50^{\circ} \mathrm{C}$. Dissolve the entire precipitate in $70 \%$ ethanol and add $4 \mathrm{ml}$ concentrated HCl and $6 \mathrm{gm}$ phenol. The stain keeps many months and gives the best results after 2 weeks.

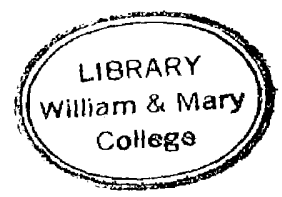

51 
Appendix VI

Embeding in Plastic

1. Remove methyl salicylate from brain with 2 changes of absolute ethanol I hour each change

2. Soak brain in 3 changes of absolute ethyl ether $\quad 45$ minutes each change

3. Infiltrate brain in uncatalyzed plastic*

in vacuuo 24 hours

4. Embed in catalyzed plastic and allow casting to gel for 24 hours

5. Cure in oven by slowly raising the temperature to $60^{\circ} \mathrm{C}$, maintaining this temperature for 2 hours. Slowly lower the temperature of the casting to room temperature.

6. Remove the casting from the mold, cut with a band saw and polish with progressively finer grades of sandpaper and buffing compounds.

*Caroplastic (Carolina Biological Supply Company) 


\section{REFERENCES}

ABDEL-MESSEIH AND TAWFIK, J. (1963). Effect of starvation on the activity of the hypothalamo-hypophysial system of Varanus griseus Daud. Z. Zellforsch 59, 395-404.

ACHER, R., CHAUVET, J., AND CHAUVET, M. T. (1969). The neurohypophyseal hormones of reptiles: comparison of the viper, cobra, and elaphe active principles. Gen. Comp. Endocrinol. 13, 357-360.

ANANTHANARAYANAN, V. (1955). Nature and distribution of neurosecretory cells of the reptilian brain. $Z$. Zellforsch $43,8-16$.

ANONYMOUS (1963). A manual...embedding specimens in caroplastic. Carolina Biological Supply Company, Burlington, North Carolina.

BERN, H. A. (1962). The properties of neurosecretory cells. Gen. Comp. Endocrinol. Suppl. 1, 117-132.

BRAAK, H. (1962). Uber die Gestalt des neurosekretorischen Zwischenhirnohypophysensystems von Spinax niger. Z. Zellforsch 58, 265-276.

CAMERON, M. I. AND STEEIE, J. E. (1959). Simplified aldehydefuchsin staining of neurosecretory cells. Stain. Technol. $34,265-266$.

DODD, J. M. AND KERR, T. (1963). Comparative morphology and histology of the hypothalamo-neurohypophysial system. Symp. Zool. Soc. Lond. 9, 5-27.

DOGRA, G. S. AND TANDAN, B. K. (1964). Adaptation of certain histological techniques for in situ demonstration of the neuro-endocrine system of insects and other animals. Quart, J. Micr. Sci. 105, 455-466.

FARNER, D. S. AND OKSCHE, A. (1962). Neurosecretion in birds. Gen. Comp. Endocrinol. 2, 113-147.

GABE, M. (1953). Sur quelques applications de la coloration par la fuchsine-paraldenyde. Bull. Micro. Appl. 3, 153-162. 
GABE, M. (1966). "Neurosecretion." pp. 484-491. Pergamon Press, Oxford.

GOMORI, G. (1941). Observations with differential stains on human islets of Langerhans. Amer. J. Path. 17, 395406 .

GREEN, J. D. (1951). The comparative anatomy of the hypophysis, with special reference to its blood supply and innervation. Amer. J. Anat. 88, 225-311.

GREEN, J. D. AND MAXWELI, D. S. (1958). Comparative anatomy of the hypophysis and observations on the mechanism of neurosecretion. In "Comparative Endocrinology" (A. Gorbman, ed.) pp. 368-392. Wiley, New York.

HALMI, N. S. (1952). Differentiation of two types of basophils in the adenohypophysis of the rat and mouse. Stain. Technol. 27, 61-64.

HEATH, E. H. (1965). Application of the performic acidAlcian blue-periodic acid-Schiff-orange $G$ stain to sections of pituitary glands from domestic mammals. Amer. J. Vet. Res. 26, 368-373.

HIID, W. (195I). Vergleichende Untersuchungen uber Neurosekretion im Zwischenhirn von Amphibien und Reptilien. Z. Anat. Entwgesh 115, 459-479.

ITO, H. (1964). The receptor in the ventricular wall of the reptilian brain. J. Hirnforsch 6, 333-337.

ITO, H. (1965). The neurosecretory apparatus in the ventricular wall of the reptilian brain. J. Hirnforsch $7,493-498$.

KOBAYASHI, H. AND MATSUI, T. (1969). Fine structure of the median eminence and i.ts functional significance. In "Frontiers in Neuroendocrinology 1969" (W. F. Ganong and L. Martini, eds.) pp. 3-46. Oxford University Press, New York.

LEATHERLAND, J.F. (1968). Pers . comm. to Dr. I. P. Callard. MURAKAMI, M. (1963). Weitere Untersuchungen uber die Feinstruktur der neurosekretorischen Zellen im Nucleus Supraopticus von Gecko Japonicus. Z. Zellforsch 59, 684-699.

NAYAR, S. AND PANDALAI, K. R. (1964). Neurohypophysial structure and the problem of neurosecretion in the garden lizard Calotes versicolor. Anat. Anz. 114, $270-278$. 
OOTA, Y. (1963). Fine structure of the median eminence and the pars nervosa of the turtle, Clemmys japonica. J. Fac. Sci. Univ. Tokoyo, Sec. IV, 10, 169-179.

PANDALAI, K.R. (1958). Morphology of the neurosecretory celis of Calotes versicolor. J. Anat. Soc. Inaia 7, $92-104$.

PAINDALAI, K. R. (1960). Reactions of neurosecretory cells of Calotes versicolor to dehydration, stress, variations in temperature, blinding and injection of sex hormones. J. Anat. Soc. India 9, 88-96.

PANDALAI, K. R. (1966). Neurosecretory phenomena with particular reference to reptiles. J. Anat. Soc. India $15,75-91$.

PANDAIAI, K. R. AND SHEELA, R. (1969). Hypothalamic control of the pars intermedia of the pituitary gland in the garden Iizara, Calotes versicolor. Gen. Comp. Endocrinol. Supp1. 2, 477-484.

PHILIBERT, R. I. AND KAMEMOTO, F. I. (1965). The hypothalamohypophyseal neurosecretory system of the ring-necked snake, Diadophis punctatus. Gen. Comp. Endocrinol. 5, $326-335^{\circ}$

SCHARRER, E. (1951). Neurosecretion. X. A Relationship between the paraphysis and the paraventricular nucleus in the garter snake (Thamnophis sp.). Biol. Bull. IOI, $106-113$.

SCHARRER, E. (1953). Das Hypophysen-Zwischenhirnsystem der Wirbeltiere. Verhandl. anat. Gesellsch. 51, 5-29.

SHEELA, R. AND PANDALAI, K. R. (1968). Reaction of the paraventricular nucleus to dehydration in the garden lizard, Calotes versicolor. Gen. Comp. Endocrinol. 11, 257-261.

SOKOL, H. W. AND VALTIN, H. (1967). Evidence for the synthesis of oxytocin and vasopressin in separate neurons. Nature $214,314-316$.

STEEL, R. G. D. AND TORRIE, J. H. (1960). "Principles and Procedures of Statistics!" McGraw-Hill Book Company, Inc., New York. 